\title{
Humor and Social Media: A Linguistic Analysis of Some Egyptian Coronavirus Memes
}

\author{
Dr. Menna Mohammed Salama El-Masry \\ Lecturer of linguistics, Faculty of Arts, Banha University
}

\begin{abstract}
:
The paper aims at investigating verbal humor in some selected Egyptian web memes about Corona Virus. It also aims at identifying the different strategies and techniques used by memes' producers to create humor. In order to carry out these goals, Attardo's (2014) General Theory of Verbal Humor is used as a methodology of this research. General Theory of Verbal Humour consists of six knowledge resources which are called (KRs): a) script opposition, b) logical mechanism, c) situation, d) target, e) narrative strategy and f) language. Results show that "possible/impossible" and "normal/abnormal" oppositions are the two major types of script opposition in the corpus. Analogy and exaggeration, on the other hand, are the most common logical mechanisms to create humor in memes.
\end{abstract}

\section{Key words:}

verbal humor, script opposition, web memes, knowledge resources, coronavirus. 
الفكاهة ووسائل التواصل الأجتماعي: تحليل لغوي لبعض الميمات المصرية عن

$$
\text { فيروس كرونا }
$$

د. منه محمد سلامة المصري

$$
\text { مدرس اللغويات - جامعه بنها- كلية الاداب }
$$

\section{ملخص البحث باللغة العربية:}

يهدف البحث إلي دراسة وتحليل إستراتيجيات الفكاهه اللفظية في بعض الميمات المصرية التي ظهرت في مختلف وسائل التواصل الاجتماعي عن فيروس كرونا. ومن أجل تحقيق أهداف البحث أعتمدت الدراسة علي نظرية العالم

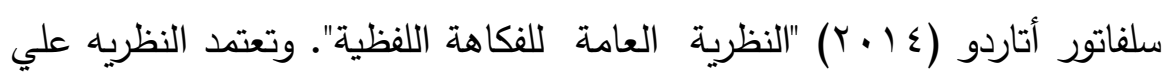
ستة عناصر أساسيه تسمي بعناصر المعرفة وهم: اللغة واستراتيجية السرد والموقف والهدف والآلية المنطقية والمعارضة النصيه. وأثبتت الدراسة أن أنواع المعارضة النصية الطبيعية والغير طبيعية والممكنة والغير ممكنة هما أكثر الأنواع شيوعا. كما أن المبالغه والتناظر هما أكثر الآليات المستخدمه لفهم المعارضه النصية وتحقيق الفكاهة.

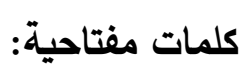
الفكاهة اللفظية، المعارضة النصية، الميمات، عناصر المعرفة، فيروس

$$
\text { كورونا. }
$$




\section{Humor and Social Media: A Linguistic Analysis of Some Egyptian Coronavirus Memes}

Dr. Menna Mohammed Salama El-Masry

مجلة وادي النيل للاراسات والبحوث الإنسانية والاجتماعية والتربوية (مجلة علمية محكمة)

\section{Introduction:}

Humor is "a ubiquitous, pervasive, universal phenomenon potentially present in all situations in which people interact" (westwood, 2008, p.621). It occurs daily in our life. Every day, we can read jokes in newspapers, see satirical comics and cartoons in different media platforms and engage in absurd situations with our friends and family members. Humor is an integral part of every society as it is one of the different means of social interaction and it is a central aspect of daily conversations. It is also a clear-cut fact that all human beings naturally participate in humorous speeches and situations.

Zabalbeascoa (2008) notes that humor has two main features: It is a social phenomenon and it is also culture-related. Westwood (2008, p.621) believes that humor is a complicated psychological and mental phenomenon which includes "cognitive, emotional, behavioral, psychological and social aspects that have a significant effect on individuals, social relations and social systems". Ortega (2013) states that there are two connected stages existing in humor: humor competence and humor performance. Humor competence is the ability of the speaker and the listener to understand humor in a specific context and humor performance is "the desire as well as the willingness to appreciate humor" (p.596).

Attardo (1994) defines humor as "an all-encompassing category, covering any event or object that elicits laughter, amuses, or is felt to be funny" (p.4). This means that humor aims to stir laughter and to amuse the audience and the interlocutors and it is the core of humor performance and humor competence processes.

On the other hand, humor and media are interrelated phenomena from cartoons and comics to comic shows, sitcoms and stand up comedies, "media do thrive in linguistic manifestations of humor" (Chovanec and Ermida, 2012, p,11) Actually, the study of humor and media has attracted the interest of researchers in 
مجلة وادي النيل للاراسات والبحوث الإنسانية والاجتماعية والتربوية (مجلة علمية محكمة)

(ISSN : 2536 - 9555)

different fields for centuries. Many researchers have been made to investigate long and short humorous texts which can be seen as "complex communicative acts which draw upon certain mental process both in their production and their reception (Rochmawati, p.150).

Egyptians are humorous people by instinct. They use humor to build affinities, negotiate relations and to overcome their social and economic problems. Coronavirus is a wide spread epidemic which invades the world in a very short time and it causes deadly and terrible losses in all developed, developing and poor countries. In order to overcome these loses psychologically and to get rid of tensions, Egyptians tend to laugh. They make many satirical and ironical comics which mock Coronavirus and its effects and they post them in different media platforms.

\section{Objectives of the research:}

The main aim of this study is to analyze the linguistic aspects of verbal humor in some selected Egyptian memes about Coronavirus. In the light of GTVH, it also aims to investigate the different verbal humorous strategies and techniques which are employed in the selected comics to produce humor. Thus, presenting a classification of the different types of humor in the selected comics. The research also shows how humor in memes has been produced via verbal mode.

\section{Research questions:}

In order to fulfill the previous goals, the research tries to answer the following questions: 1) What are the different ways and techniques in which humor is created in internet memes? 2) How does the construction of Web memes contribute to the creation of humor? 3)To what extent Attardo's Genral Theory of Verbal Humor is applicable to web memes?

\section{Theories of Humor:}

Humor is "a multi-disciplinary field of research" (mulder $\&$ Nijholt, 2002, p.3). Many theories of humor have been developed by famous scholars and researchers such as Aristotle and Plato who 


\section{Humor and Social Media: A Linguistic Analysis of Some Egyptian Coronavirus Memes}

Dr. Menna Mohammed Salama El-Masry

مجلة وادي النيل للاراسات والبحوث الإنسانية والاجتماعية والتربوية (مجلة علمية محكمة)

have asked one major question of why people laugh at specific situations and they do not laugh at others. Attardo (2014) states that there are three groups of humor theories: those based on "hostility", those based on "liberation" and those based on "incongruity" (p.369).

\subsection{Superiority / Hostility Theories}

Superiority theory's tents are similar to the ideas of Plato and Aristotle whose oldest theories have been investigated the aggressive side of humor which occurs when the speaker tries to humiliate the listener (Moreall, 1987). Scholars believe that Plato's text is "the archetype of the aggression theories" (Attardo, 1994, p.19).

Bergson in Moreal (1987, p.117) believes that we laugh at people's mechanical behaviors not from the individuals themselves. Attardo (1994) states that we laugh as "a result of a perceived superiority to some character in the joke" (p.8). In the modern era, Thomas Hobbes is the first one to investigate superiority/ aggression theory. Hobbes has "formulated most forcefully the idea that laughter arises from a sense of superiority of the laughter towards some object" (p.49) which is the butt of the joke.

Abdalion (2005) notes that superiority theory "has a great deal to offer in terms of psychological explanations of laughter" (p.11). This explains that in each humorous situation there is a winner and a loser. The listener feels a relation of superiority to the loser and this triggers laughter. This means that people usually laugh at the faults of others. Tomoioaga (2015) affirms the psychological aspect of hostility/ superiority theory saying that superiority theories "deal with the psychological causes and effects of humor" (p.160). 
(ISSN : 2536 - 9555)

\subsection{Incongruity theories}

Incongruity theory is "the most popular current theory of humor" (Morreal, 1987, p.6) because incongruity or opposition is the most important element to create laughter according to modern research on humor. Tomoioaga (2015) believes that incongruity theories "are oriented towards the cognitive mechanisms of humor" (p.160). According to this theory, humor has been created when there is a clash or a conflict between what is expected and what actually happens. In other words, it focuses on the contrast between the hearer's expectations and the speaker's sudden resolution of the situation (p.162). As mentioned in (Attardo, 1994), Kant and Schoenhauer are the first authors to investigate the notion of the term incongruity in modern age (p.47).

Incongruity is connected to surprise which is a result of the clash between the situation's opposite meanings. Incongruity is "a stimulus" and surprise is "a response to this stimulus" (Attardo, 2014b, p.384). Moreall (1987) explains that "the cause of laughter in every case is simply the sudden perception of the incongruity between a concept and the real objects" (p.55).

William (1940) explains the importance of the term incongruity when he says that the basic cause of humor in any situation is "contradiction" or "incongruity" (p.72). He believes that at the end of any humorous situation, the recipient tries to realize or solve the incongruity of the situation, so that he can make the punch line clear. Hence, humor is expressed and laughter is stirred. In sum, "incongruity theories are conceptually closer to linguistic theories" (Attardo, 1994, p.49) as the core of these theories is the "cognitive resolution" of an utterance or a situation that is" irresolvable" (Abdalian, 2005, p.4).

\subsection{Release Theory}

Release theory or release of relief theory, as Freud (1960) called, is based on "the idea that joking has a vital psychological function to perform (Abdalian, 2005, p.7). Rutter (1997) admits that relief theory is closely related to psychology. Release theories 


\section{Humor and Social Media: A Linguistic Analysis of Some Egyptian Coronavirus Memes}

Dr. Menna Mohammed Salama El-Masry

مجلة وادي النيل للاراسات والبحوث الإنسانية والاجتماعية والتربوية (مجلة علمية محكمة)

conclude that humor is used to release emotions and to make one feel liberated especially when talking about taboo issues. Release theories believe that humor releases psychic tensions and it also releases humans from "conventions and laws" (Attardo, 1994, p.50).

Norrick (2003) states that Freud is the founder and the most proppant of release theories. He is the first one to speak about jokes and he also posits a psychoanalytic theory of humor known as release or relief theories. Freud believes that laughter is "an outlet for psychic or nervous energy" (cited in Moreal, 1987, p.11). According to Freud, any humorous situation must contain a psychic energy which triggers or releases the suppressing feelings and emotions and this is the main reason for laughter.

\subsection{Linguistic Theories of Humor}

Dealing with humor as a linguistic phenomenon is a complex task and it differs greatly from cultural, sociological, psychological studies. Moreover, there have been many theories of humor, most of them pay a great attention to philosophical and psychological aspects of humor and from a linguistic perspective, "studying humor offers an opportunity to the understanding we have of semantic phenomena and the cognitive process that interpret meaning" (Abdalian, 2005, p.4). Until 1985 "no coherent theory of humor had been proposed, that would have been capable of handling humor at all linguistic levels" (Attardo, 2003, p.1287), and actually all linguistic researchers were limited to the study of wordplay and irony. Actually, the most prominent theories of linguistic humor are Raskin's (1985) Semantic Script Theory of Humor (SSTH) and Attardo's (1994) General Theory of Verbal Humor (GTVH). 
مجلة و ادي النيل للاراسات والبحوث الإنسانية والاجتماعية والتربوية (مجلة علمية محكمة)

(ISSN : 2536 - 9555)

\subsubsection{Semantic-Script Theory of Humor (SSTH)}

It is Raskin's (1985) Semantic Script Theory of Humor which changed the prevailed perspectives on studying humor. It is clear that semantic script theory belongs to incongruity theories and it establishes "the semantic/ pragmatic foundation of humor" (Attardo, 2003, pp.1288-1289).

A good introduction to modern Semantic theories of Humor is Grice's (1975) cooperative maxims or what is called Grice's cooperative principles which set of conversational rules that must be followed by the speaker and the listener. In any humorous situations, we have at least one speaker and one listener. The listener expects that the speaker will adhere to Grice's conversational maxims. What causes laughter is that the speaker violates intentionally or non-intentionally, one or more than one of the maxims of conversation. Raskin (1985) believes that joking or laughter is a form of "bonafide speech": a kind of speech in which one of the Grice's maxims is violated (p.150). If the listener flees from bonefide speech, he will resolve incongruity, but if he sticks to it; he will not resolve incongruity, so he will not laugh. Raskin believes that the "ability to interpret a joke ( ) is dependent upon the ease with which one can switch between bonafide communication and nonbonafide communication" (Abdalian, 2005, p.21).So, one of the most important aspects of SSTH is "its pragmatic component" (Raskin 1985, p.177).

According to Raskin (1985), a text can be described as a joke if it is "compatible, fully or in part, with two different scripts" (p,99). Ritchie (2004) defines the term script as "structured configuration of knowledge about a situation or an activity" (p.20). This means that the script can provide information about an event, an action or an object and it also describes how this action is done and how it is organized. According to Attardo (2001), the script refers to some interrelated information which shows "how a given entity is structured, what are its parts and components or how an activity is done" (p.2). Raskin (1985) sees script as "a large chunk of semantic information surrounding the word or evoked by it" (p.81). 


\section{Humor and Social Media: A Linguistic Analysis of Some Egyptian Coronavirus Memes}

Dr. Menna Mohammed Salama El-Masry

مجلة وادي النيل للاراسات والبحوث الإنسانية والاجتماعية والتربوية (مجلة علمية محكمة)

This evokes that the script can provide the speaker with the needed information. Attardo (1994) divides scripts into two types: macro scripts and complex scripts. The Marco scripts are "clusters of scripts organized chronologically" (p.200) and complex scripts are "scripts made of other scripts, but not organized chronologically" (p.200). An example of macro script is restaurant script which consists of some events which are organized chronologically such as "drive up to the restaurant, be seated, order food, etc." (p.200) On the other hand, war script is an example of complex script as it consists of some related scripts like army script, weapon script, victory or defeat script.

According to Raskin (1985, p.107: p.114), scripts can be opposite on different levels, the most important is the lexical one. So, he proposes three levels of abstractness to all script oppositions:

1- The concrete level which is called lexical level and it appears inside the text.

2- The intermediate level which is a general one.

3- The abstract level which is the basic category of opposition.

In the abstract level, there are three main classes of opposition: actual/ non actual, normal/ abnormal, possible/ impossible. All these classes are examples of a basic opposition between real situations and unreal situations (Attardo, 1994, p.204). The first class of opposition reveals the contradiction between the actual situation clarified in the setup of the joke and the nonactual or the un existing situation from the second script. The second opposition is established between normal situation or circumstances. The third opposition is between possible or plausible circumstances of the first script and impossible circumstances of the second script. From these three classes, Raskin (1985) lists other subclasses of opposition: good/ bad, life/ death, sex/ non sex, high/ low, absence/ non absence and so on. Hence, most scholars agree that SSTH is totally "a semantic theory of humor" (Attardo, 1994, p.222). It also 
(ISSN : 2536 - 9555)

aims to investigate the different features which make a text or a situation funny.

\subsubsection{General Theory of Verbal Humor (GTVH)}

General Theory of Verbal Humor is "the reused version of the SSTH" (Attardo, 1994, 196). Raskin and Attardo (1991) propose GTVH as developmental and a broadening of SSTH. It aims to analyze the joke through a comprehensive linguistic model. The theory proposes that in any humorous text, parameters plus script opposition must be found. These parameters are called Knowledge Resources or (KRs). These KRs are: language, narrative strategy, target, situation, logical mechanisms and script opposition.

1- Language (LA): It is "the actual verbalization of a text" (Attardo, *1994, p.196). This means how the information which is central to the joke is understood and realized. In the language resource, one can use different phonological, morphological, lexical, semantic and pragmatic devices. To create a humorous text.

2- Narrative Strategy (NS): It is the genre of the joke. It is the form that the joke takes, for examples, a dialogue, a riddle, a narrative, a political or a religious text, etc. It is the style which is used to present the joke.

3- Target (TA): It is the optional narrative strategy. It can be found in some jokes and it disappears in other jokes. Target shows "who is the butt of the joke" (Attardo, 1994, p.198). This means target explains to whom the joke is targeted.

4- Situation (S): It means the context wherein the joke takes place. It is a description of characters, actions and objects within the joke.

5- Logical Mechanism (LM): The Logical Mechanism of the joke is the logic which makes the joke functional. It is the mean or the vehicle through which incongruity is resolved. Attardo (1994, p.199) defines logical mechanism as "the parameter that accounts for the way in which the two senses in the joke are brought together". Attardo (2002) lists all known logical mechanisms that can be found in any 


\section{Humor and Social Media: A Linguistic Analysis of Some Egyptian Coronavirus Memes}

Dr. Menna Mohammed Salama El-Masry

مجلة وادي النيل للاراسات والبحوث الإنسانية والاجتماعية والتربوية (مجلة علمية محكمة)

humorous situation and they are: role reversal, golden path, inferring consequences, coincidence, proportion, exaggeration, meta-humor, role-exchange, juxtaposition, figure- ground reversal, analogy, false analogy, parallelism, potency mappings, faulty reasoning, referential ambiguity, and chiasmus (p.18). Hempelmann and Attardo (2011) states that "the SSTH can be classified as an incongruity theory and the GTVH as an incongruity- resolution- theory" (p.130).

\section{The structure of jokes}

In humor research, the term joke has two interwind senses. The first is that joke is a type of humorous discourse; the second is that it is an "instance of humor" (Attardo, 2014, p.418). The term joke comes from the Latin word "iocus" which means "play" or "game" (p.418). Jokes vary in "length", "topic" and "description" (Taylor, 2014, p.456).

In order to be defined and described as a typical humorous joke, it must have two or more interpretations and it also has to carry some complex processes: a first sense (S1) has to be established, the listener suddenly feels a second sense (S2), a passage from S1 to S2 occurs, so laughter takes place. "A disjunctor", or an "indicator" or a "switch trigger" is the major element which causes the sudden movement from S1 to S2 (Attardo, 1994, p.95).

According to Hockett (1977), the joke consists of three basic components: build up, pivot and punch line. The buildup is the body of the joke. It is a sentence which introduces the joke. The pivot is the group of words or phrases around which incongruity is built. The punch line is the conclusion of the joke. Taylor (2014) defines punch line as "an expected twist in narrative resulting in humor", (p.612).

Attardo (2001) presents two important notions in analyzing jokes: Jab line and Punch line in which through them script 
(ISSN : 2536 - 9555)

opposition has been produced. The punch line is "a segment of a text which disrupts the flows of the narrative for humorous purposes" (Oltean, 2013, p.144). It is a word or a phrase which force the reader to think of the second opposed script. In contrast to punch line, Jab line is seen as an "integrated element of the narrative" (p.144). This means that the main difference between jab line and punch line is that the second is positioned at the end of the joke and the first can appear at any position (Attardo, 2001).

Attardo (1994) explains two types of jokes: "referential jokes" and "verbal jokes" (p.95). Referential jokes are based on the meaning of the given text. On the other hand, Verbal jokes are based on "the meaning of the different elements of the text" (p.95). So, it is closely related to the phonological, morphological and syntactic realization of the text.

Attardo (2014 c) puts another distinction between "canned" jokes and "spontaneous" or "conversational" jokes. A canned joke is "a short narrative ending in a punch line" (p.418). Conversational jokes are those jokes which are "improvised on the fly, without prior rehearsal" (p.418).

According to Attrdo (2003) and Schmitz (2002), there are here types of jokes: universal, cultural and linguistic. Universal joke is a kind of joke in which humor is understood from the context. In cultural joke, humor and laughter are closely connected to culture. In linguistic jokes, understanding humor is based on some linguistic features. In recent research, jokes are classified according to their content, so we have "ethnic jokes", "Jewish jokes", "polish jokes" and so on (Attardo, 2014 c, 418). Hempelman (2008) sees comics and cartons as "jokes that convey part of the necessary information through pictures" (p.611). Humor in these texts is created via visual and verbal modes and a punch line must be present in order to realize humor.

\section{Verbal Humor / Language Specific Humor}

Conversational Humor is "an umbrella term covering a variety of semantic and pragmatic types humor" which occur in different 


\section{Humor and Social Media: A Linguistic Analysis of Some Egyptian Coronavirus Memes}

Dr. Menna Mohammed Salama El-Masry

مجلة وادي النيل للاراسات والبحوث الإنسانية والاجتماعية والتربوية (مجلة علمية محكمة)

fictional or real situations and contexts (Dynel, 2009, p.1284). The term language specific humor of verbal humor is used to describe humor that is expressed verbally via different linguistic and figurative devices. As an umbrella term, many researches have been done to present different classifications of the term. Monoro (1953) has presented a taxonomy of humor based on the different situations and contexts people find them humorous such as unexpected events, misfortunes or reversal of events. Goldstein \& Mcghee (1972) has introduced three other types of humor and they are aggressive wit, sexual wit and nonsense wit. Norrick (1984) has discussed new categories of humor such as sarcasm, irony, satire and asserted that other types such as pun, allusion, metaphor, simile, hyperbole are sub-categories of word play. The research follows Dynel (2009) classification of verbal humor. Dynel has discussed in her research the interrelated and the overlapping classifications of humor and she has presented a comprehensive list of the multiple types of verbal humor including witticism, irony, pun, simile, metaphor, hyperbole, spoonerism, sarcasm, register clash, retorts, teasing, banter, puts down and self-denigrating humor. The following lines are a detailed explanation of Dynel's (2009) model of verbal humor.

Norrick (1984) defines metaphor and simile as kinds of comparison. Simile means comparing two items using connecting words such as "like" or "as". Metaphor, on the other hand, is to find a similarity between a tenor and a vehicle without using connecting words. Hyperbole, according to (Norrick, 1993), is an exaggeration, i.e., to exaggerate in using language.

Irony is "a source of humor, and humor is an effect of irony" (Orrega, 2013, p.598). Attardo (2000) sees irony as "a pragmatic phenomenon" which implicates the opposite meaning of what has been said and tigers the importance of context (p.813). So, in its broad and wide sense, irony is defined as saying something while meaning something else and the term irony comes from the Greek word "eironeig" which means "dissimulation" or "concealing" 
(ISSN : 2536 - 9555)

(Attardo, 2007, p.399). Aristotle was the first one to use the term irony as a figure of speech. A basic distinction has been made between verbal irony, situational irony and dramatic irony. Verbal irony, as (Gibbs, 1994, p.362) defines it, means that the speaker says a word and means the opposite. Attardo (2000, p.794) defines verbal irony as "a linguistic phenomenon which means saying something and means the opposite. For example, a mother walks into her son's room which seems missy and says" Honey your room is so tidy" (Gibbs, 1994, p.362). Situational irony or irony room of fate, as Sulis et al. Call it, refers to "the state of affairs or events which reverse what has been expected" (p.133). This means that it refers to a situation in which there is a contradiction between what is expected to happen and what actually happens, for example, an injured kid was runover by an ambulance (Largerwelf, 2007, p.175). Dramatic irony is a situation in which the audience knows something that the characters do not know. Attardo (2000) defines sarcasm as an "overtly aggressive type of irony" (p.795). This means that the main difference between sarcasm and irony is the target of each one. Sarcasm targets to attack and this does not occur in irony. Moreover, sarcasm is more aggressive and offensive than irony (Dynel, 2014, Attardo, 2007). Some visual markers of irony and sarcasm are "Eye brows: raised or lowered, eyes: wide open, squinting, rolling, winking, nodding and smiling" (Attardo, et al., 2003, p.254).

Pun is considered "the sole purview of the linguistics of humor" (Attardo, 2018, p.90). It is the most famous type of verbal humor as it is widely studied and investigated in humor research. Dynel (2009) defines pun as "a humorous verbalization which has two interpretations" (p.129). Koestler (1964) defines pun as "a bisociation of a single phonetic form with two meanings. The two strings of thought tied together by an acoustic knot" (cited in Dartington, 2009, 1795). Hempelmann (2014) describes pun as "a type of joke in which one sound sequence (word) has two meanings" (p.613). This similarity creates a connection between two meanings from which humor is produced. Pun is "the most obviously bisociative of all forms of humor" (Partington, 2009, 


\section{Humor and Social Media: A Linguistic Analysis of Some Egyptian Coronavirus Memes}

Dr. Menna Mohammed Salama El-Masry

مجلة وادي النيل للاراسات والبحوث الإنسانية والاجتماعية والتربوية (مجلة علمية محكمة)

p.1795). Homonymy, paronymy and homophony are the three different types of puns. Homonymy is a word which has more than one meaning, for example: a woman was created from man's rib. She has been ribbed ever since (Dynel, 2009, 12911). Here the word rib has two different meanings. Homophones are two words "which their sounds are identical, but they are written differently, for example, Loo and Lou (Hempelmann, 2014, 2014, 614). Paronymy means that two sound sequences are similar, but they are not identical, for example, why did the cookie cry? Its mother had been away for so long (a wafer) (Pepicello \& Thoman, 1984, p.59).

Witticism is "a clever and humorous textual unit interwoven into a conversational exchange" (Dynel, 2009, p.1288). Witticism is closely understood from the context, for example: political skill is the ability to foretell what is going to happen tomorrow, next week, next month, and next year and have the ability afterwards to say why it didn't happen" (p.1289). There are two forms of register clash: upgrading and downgrading. Upgrading means "using items from a higher register in informal discourse" (p.1292). This means using formal language in informal situations. Downgrading, on the other hand, involves using informal language in formal situations.

Retort, according to Norrick (1993), is a witty response to a previous turn. It aims to amuse the audience and it overlaps with witticism. For example: A: What do you do when a bird dirties your windscreen? B: Never ask her out again (Dynel, 2009, 1293). One of the most prominent features of a retort is that the interlocutor pretends misunderstanding the preceding turn. A putdown is an insult directed to someone to put him down. In putdowns, the speaker ridicules or mocks someone to evoke laughter, for example: they used to put your face in the dough to make the gorilla biscuits (Terron and Ashforth, 2002), you must be an experiment in artificial stupidity (Dynel, 2009, p.1295). 
مجلة وادي النيل للارسات والبحوث الإنسانية والاجتماعية والتربوية (مجلة علمية محكمة)

(ISSN : 2536 - 9555)

Teasing is a "a higher- order concept embracing jocular utterances performing a variety of pragmatic functions such as mocks, challenges or threats" (Dynel, 2009, 1294), for example:

Female: You are a thief and a liar.

Male: I only lied about being a thief (p.1294).

Norrick (1993, p.29) defines banter as "a rapid exchange of humorous lines oriented towards a common theme, through aimed primarily at mutual entertainment rather than topical talk" (Dynel, 2009, p.1295), for example:

A: You are a bad girl, are not you?

B: You are a dork.

A: You do not get out much, do you?

B: You are cute, like my little sister (Lehikomen, 2012, p.8).

In self denigrating humor, the speaker "directs a brickbat at him/herself" (Dynel, 2009, p.1296). It is also called selfdisparaging or self- mockery humor (Norrick, 1993), for example: my brain must be a standby mode or in today's performance, the role of idiot will be played by myself (Dynel, 2009, p.1296). Spoonerism means speech errors. Oxford English Dictionary defines spoonerism as "a verbal error in which the speaker accidently transposes the initial sounds or letters of two or more words; for example: teep a cape and keep a tape (Vousden, 1996, p.18).

\section{Memes:}

The term meme was firstly appeared in Richard Dawkins book The Selfish Gene (1976). According to Dawkins, meme is defined as a unit for carrying cultural ideas or behaviors similar to how genes carry genetic information from one generation to another. (cited in T. Shubeck and Huette, 2015, p.2182). Like genes, memes move from mind to mind through communication and social learning. After 40 years of Dawkins definition of Meme, Davidson (2012) defines memes as "a piece of Culture typically a joke, 


\section{Humor and Social Media: A Linguistic Analysis of Some Egyptian Coronavirus Memes}

Dr. Menna Mohammed Salama El-Masry

مجلة وادي النيل للاراسات والبحوث الإنسانية والاجتماعية والتربوية (مجلة علمية محكمة)

which gains influence through online transmission" (p. 122). This means that memes are closely connected to culture, so it is difficult for those who are unfamiliar with a specific culture to sense and recognize them easily. Anugrah Putra \& Triyono (2016) explains memes' cultural aspect by defining them as " culture makers" which represent "the cultural background where those memes are used" (p. 51). As mentioned in (Kostadinovska \& Shalevska, 2018), the term meme came from the Greek word "mimema" which means imitation (p. 160).

\subsection{Web memes:}

With the advancement of technology, a new term has been appeared and it has been popular among social media users that is internet memes or web memes or website memes. Social media presents different websites and platforms for internet users to "share their opinions" (Lin et al, 2014, p.143). In social media realm, memes work as an effective mode of communication similar to language. Because of its efficiency, net users prefer to use memes than words to express their ideas. So, Anugrahputra \& Triyono (2016) admits that memes are "the vehicle to transmitted ideas knowledge and propaganda" (p. 51).

Oxford English Dictionary defines the term internet meme as "an image macro" which connects an image to a catchphrase to produce a humorous effect". This means that internet meme is a combination of images and phrases which produce a joke about a certain topic. According to (kostadinovska \& Shalevska, 2018) internet memes are "jokes that are presented through "image text "or "gif text" or just "a plain text "(p. 159) and they spread through different internet platforms. The most popular type of memes is that of an image plus a small text. This genre contains multiple cultural and political social and religious references in it requires a big knowledge to be explained. So Anugrah Putra \& Triyono (2016) mentions that memes are "a form of digitization from the participatory culture of the internet" (p. 49). Dynel (2006) defines 
مجلة وادي النيل للاراسات والبحوث الإنسانية والاجتماعية والتربوية (مجلة علمية محكمة)

(ISSN : 2536 - 9555)

internet memes as " any artifact" such as film video or picture which appears on the internet and produces "countless derivatives by being imitated and remixed" (p. 662). The term internet meme was coined by Mike Goodwin in 1993 (cited In F. Joshua, 2020, p. 77). According to Goodwin internet memes are defined as "hijacking of the original idea" (p. 77). They are the virtual online entertainment tools" that are meant to be "shared and creatively recreated" ( kostadinovska \& Shalevska, 2018, p160). Memes have many functions and they also have many distinguished futures. The most important function of memes is that they work as commentary, criticism or entertainment. Moreover, memes are "never constructed by only one user of the network " (Ostanina \& Majdzinska, 2019, p. 2). Shifman (2014) summarizes and discusses three qualities of memes and they are: gradual propagation from individuals to society and reproduction through imitation and diffusion (p. 18).

In Egypt Webb memes are produced by "a variety of anonymous users and popular pages like asa7be or Egypt sarcasm society (Elkhachab, 2018.p1). For Egyptians, memes are like "small capsules of attitudes or emotions that poke fun" (Adel, 2019,p.1.) These satirical Egyptian capsules depend on "popular movie gags (effihat)", "caricatures", "funny movie lines (nokat)" and "comic strips (comics)" (p.1). For this reason, the researcher chooses some gags (effihat) which appear in the time of the lockdown. These memes reflect how the Egyptians try to overcome the effects and the aftermath of Corona Virus through laughter. Moreover, coronavirus or covid-19 is a topic of the day in the time between 1_2_2020 until now. So, the researcher tries to show and emphasize Egyptians sense of humor even in the time of crisis. Twenty memes have been collected from different sites and platforms. The research Focuses on image- text memes to show the complex relation between them while analyzing humor. 
Humor and Social Media: A Linguistic Analysis of Some Egyptian

Coronavirus Memes

Dr. Menna Mohammed Salama El-Masry

مجلة وادي النيل للاراسات والبحوث الإنسانية والاجتماعية والتربوية (مجلة علمية محكمة)

\section{Data analysis:}

Figure 1.

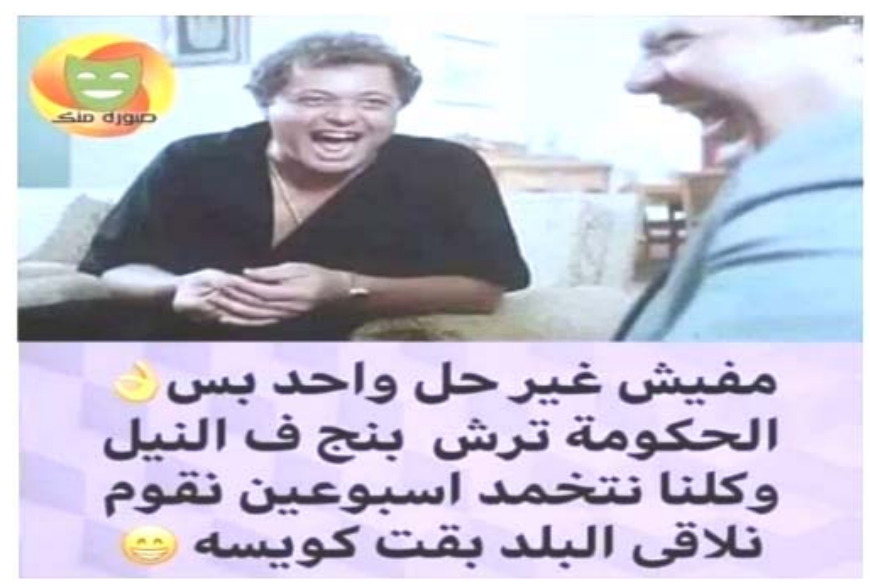

In a conversation between the two brothers Gamal Abu-Alazm , the drug-addict who fails to complete his university degree, and Salah Abu-Alazm, who has a $\mathrm{PhD}$ in science, Mahmoud Abdelaziz suggests a magical solution for corona virus which perplexes scientists all over the world. The solution is that the government must add anesthetic to the Nile river so that all Egyptians can sleep for two weeks. When they awake up, there will be no corona virus in Egypt.

In this shot, there are two types of script opposition: the first one emerges from the meme's template and it is the actual vs. nonactual opposition. Actually, Salah, the scientist, is the one who gives advice to his brother throughout the film's scenario. In this situation it is Gamal who gives a scientific opinion. The second script opposition arises from the bottom caption. Here, it is normal for the governments and scientists around the world to search for a vaccine or a solution for corona virus, but it is abnormal to use 
(ISSN : 2536 - 9555)

anesthetic as a solution. In order to solve this opposition, exaggeration is used as a logical mechanism. The caption of the meme is written in present tense and the meme's producer uses the attached pronoun "Na" (we) in "netkhmed" (sleep) and "nilaqy" (find) because it is a matter of all Egyptians. This meme is targeted to all Egyptians. It is a kind of satire of what is called "waei alshab" (people awareness).

Script opposition: normal vs. abnormal - actual vs. non actual

Logical mechanism: exaggeration

Target: Egyptian people

Narrative strategy: web meme

Context: a scene from Alkayf movie

Type of humour: satire

Figure 2.

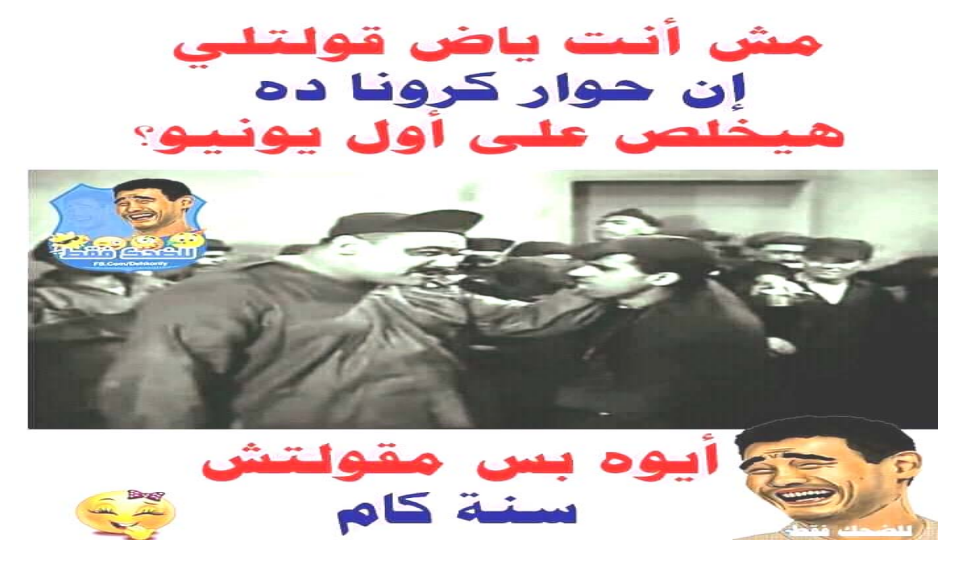

The meme's mechanism depends on recalling a conversation between Mohamed Reda (Jinjil Abou Shaftorah), the dangerous criminal, and Aldaif Ahmed (Nafsa) who is responsible for cooking inside the jail. In the original scene, Jinjil rebukes Nafsa announcing that there is something wrong inside his meal: "there is extra salt in the food". Nafsa tries to defend himself saying " you 


\section{Humor and Social Media: A Linguistic Analysis of Some Egyptian Coronavirus Memes}

Dr. Menna Mohammed Salama El-Masry

$$
\text { مجلة وادي النيل للاراسات والبحوث الإنسانية والاجتماعية والتربوية (مجلة علمية محكمة) }
$$

do not tell me how many salt spoons to put in the food". The meme's producer recalls the same situation and adds a beautiful setup and an attractive punchline. Jinjil rebukes Nafsa again but for telling him that corona virus is to disappear at June. It is possible for anyone to say that corona virus is to disappear on June. What is impossible is Nafsa's answer "yes, but I do not determine a specific year." This answer alludes that corona virus will last for a long time and according to the news, there will be a vaccine by the end of December. So, there will be no virus. The logical mechanisms which clarify script opposition are analogy and juxtaposition. The meme's set up is a kind of interrogative sentence and the punch line is a declarative statement. The producer of this meme uses some Egyptian's colloquial expressions like "yad" (boy) and "hewar" (topic) to attract the respondents. The meme mocks many rumors which say that June is the end of Corona virus.

Script opposition: possible vs. impossible

Logical mechanism: exaggeration and juxtaposition

Target: Egyptian people

Context: a scene from Talatyn Youm Fy Alsijn (Thirty Days in Jail).

Figure 3:

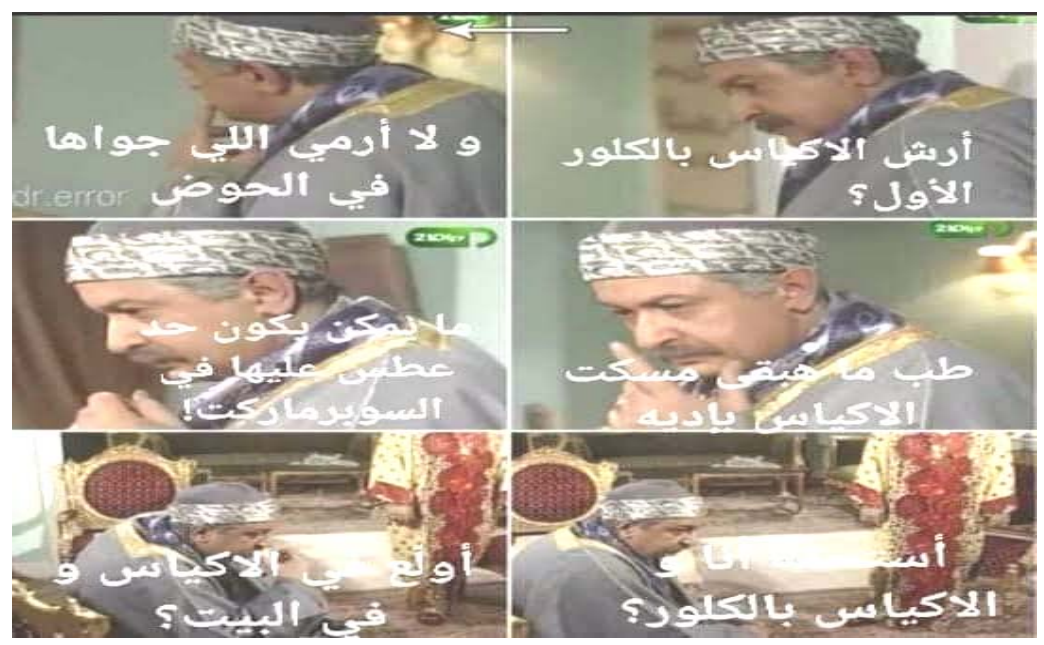


مجلة وادي النيل للار اسات والبحوث الإنسانية والاجتماعية والتربوية (مجلة علمية محكمة)

(ISSN : 2536 - 9555)

The image is originally cut from the famous Egyptian T.V. series Lan Aeish Fi Jilbab Aby ( I will Not Live in My Father's Jilbab/ I Will Not Be Like My Father) which tells the story of the successful businessman Abdalghafor Alboraei and his family, The meme's template depicts Abdalghafor and it is clear that he is thinking of something important that needs and requires deep thinking. The caption of the meme clarifies what he thinks of: corona virus. Abdalghafor, here, exemplifies all Egyptian men and women who live in a state of perplexity and confusion since the appearance of this pandemic. The connection between the image of Abdelghafor and the captions creates actual and non-actual script opposition. The actual script is that all Egyptians try to use chlorine and other disinfectants in order to be safe. What is non-actual is the last left caption which constitutes the punch line of this meme. Abdalghafor announces in a satirical way that the only solution is to set fire on bags in order to be safe from the virus. This meme is a kind of satire of what Egyptians do at the beginning of the pandemic. The meme is produced in an exaggerated way which resolves the script opposition. The producer of the meme uses the attached pronoun " Aa" which means "I", so everyone who reads the meme can feel that he is Abdalghafor. The colloquial Egyptian dialect is clear in terms such as " astahma" ( take a shower), "arosh" (spray), "army" (throw) and "awalae" (burn).

Script opposition: actual and non-actual

Logical mechanism: exaggeration

Target: Egyptians who are obsessed with sterilizing their shopping

Context: a scene from the Egyptian series Lan Aeish Fi Jilbab

Type of verbal humor: satire 


\section{Humor and Social Media: A Linguistic Analysis of Some Egyptian Coronavirus Memes}

Dr. Menna Mohammed Salama El-Masry

مجلة وادي النيل للاراسات والبحوث الإنسانية والاجتماعية والتربوية (مجلة علمية محكمة)

Figure 4:

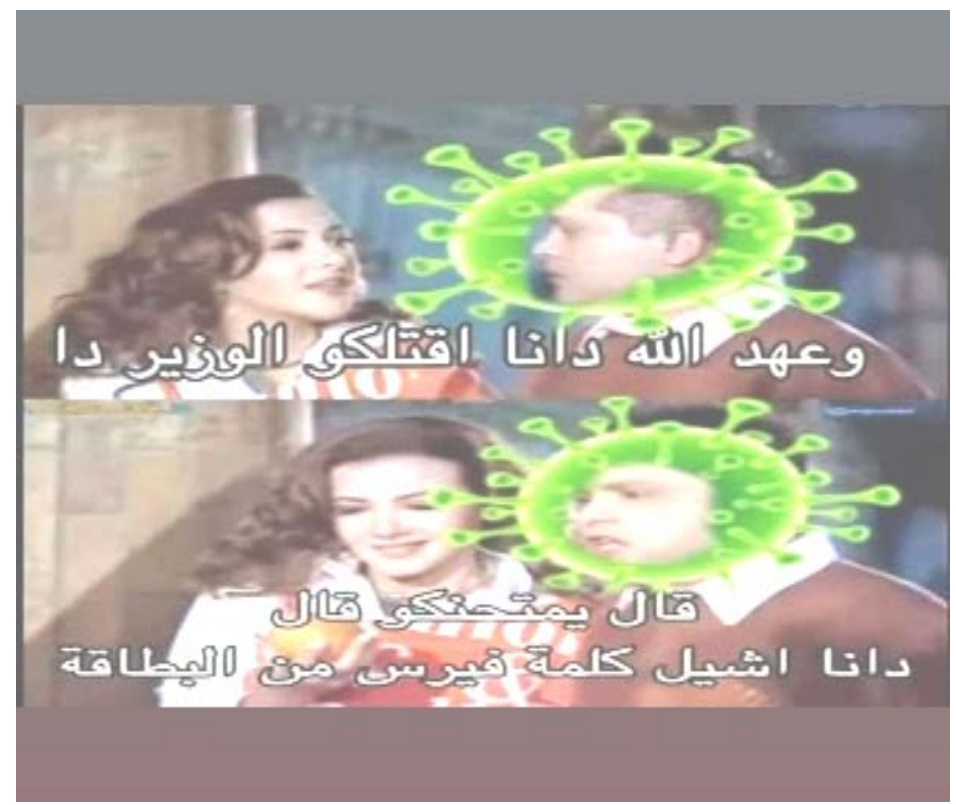

This image is originally adopted from the Egyptian movie Yana Ya Khalty (Either Me or My Aunt) in which "Mohamed Heneidy" loves his colleague "Donia Samir Ghanim", but her mother, who is obsessed with genies, demons and spirits, refuses this love. In this scene, Nawal asks Timor a surprising question which is a set up of the meme "what will you do if someone annoys me?" Timor comically answers: "no one can dare to annoy you and if this happens, I will delete the word male from my ID". This situation is imitated. but with a new caption about corona virus effects. Nawal asks Timor: "what will you do if the minister of education announces the convening of exams in coronavirus's time?" Nawal's question is a normal one which is asked by all university and school students. Timor's answer is abnormal and unexpected one: "I swear I will kill this minister and I will delete the word virus from my ID". 
(ISSN : 2536 - 9555)

This satirical script opposition is clarified by exaggerating the situation and understanding the love relation between Timor and Nawal in the original film (analogy). The meme's producer uses colloquial expressions such as "weahd Allah" (by Allah or I swear), and "ashyl" (delete). Personification plays an important role in understanding analogy as a logical mechanism. Timor describes coronavirus as a man who will delete the word virus from its ID if the minister announces the start of exams. This meme mocks Egyptian students who do not want to take exams.

Script opposition: normal \& abnormal.

Logical mechanism: false analogy \& juxtaposition.

Target: Egyptian students \& the minister of education.

Context: a scene from Egyptian movie Either Me or My Aunt. Type of verbal humor: satire.

Figure 5:

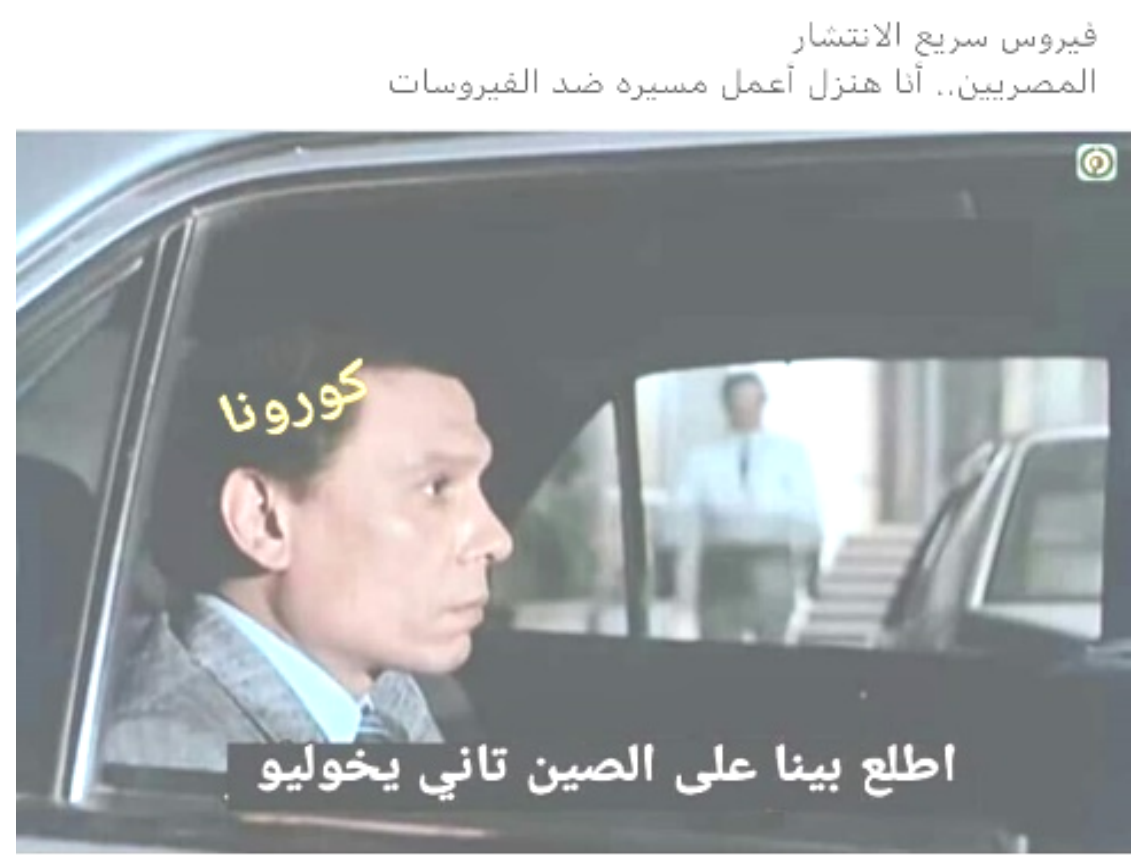




\section{Humor and Social Media: A Linguistic Analysis of Some Egyptian Coronavirus Memes}

Dr. Menna Mohammed Salama El-Masry

مجلة وادي النيل للار اسات والبحوث الإنسانية والاجتماعية والتربوية (مجلة علمية محكمة)

This meme is a conversation between two heroes "Adel Imam" (Marzouk) and "Mohammed Metwally" (kholio) from the Egyptian film Salam Ya Sahby (Bye Bye My Friend). The first line of the top caption declares that corona is a widespread and dangerous virus. It is possible for anyone to speak about the gravity of coronavirus which invades the world. The reaction of Alexandria's people is impossible. They declare that they "we will protest against the virus". It is impossible or implausible reaction. The punchline of the meme emphasizes the impossibility of the situation. The virus, which is personified in the character of Adel Imam, says "let's go to China again, Kholio". Here, exaggeration resolves the two opposed scripts. In order to emphasize the impossible script, the meme's producer uses personification. Coronavirus is described as if it is Adel Imam (Marzouk) who asks his friend (Kholio) to leave Egypt and go to China again. Here, the meme mocks Alexandria's people: the virus loses hope in Egyptians' awareness.

Script opposition: possible \& impossible

Logical mechanism: exaggeration

Target: Egyptian people

Context: an image is taken from the Egyptian film "Salam ya sahby" (Bye Bye my friend)

Type of verbal humor: satire.

Figure 6:

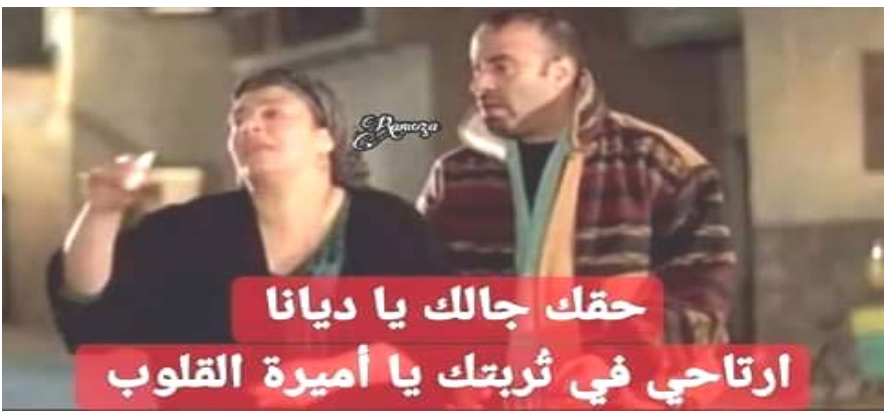

731 
(ISSN : 2536 - 9555)

United Kingdom has been announced that Prince Charles has been infected with coronavirus, so the meme's producer tries to highlight this incident by an image from the Egyptian film Allimby. The scripts which are opposed in this meme are: the life script, involving the life of prince Charles who has been infected with coronavirus, and the death script, activated by the death of princess Diana. The template here is the setup of the meme and the down caption is the punch line. "Abla kamil" who is a symbol of all Egyptian women, especially the low-class women, speaks about princess Diana saying: "finally, you got your right Diana, rest in peace, princess of hearts". Abla kamil's words activate death script which opposes Charles life script. The logical mechanism which resolves the contradiction of the two scripts is parallelism which connects Charles to Diana and highlights the rumors which say that prince Charles is responsible for Diana's death. The meme is written by a very simple colloquial Egyptian dialect. It consists of some Egyptian related expressions like "haqk galek" (you got your right) and "ertahy fe torbtk" (rest in peace).

Script opposition: life \& death

Logical mechanism: parallelism

Target: no specific target

Verbal humour: sarcasm

Context: an image from the Egyptian movie Allimby

Figure 7

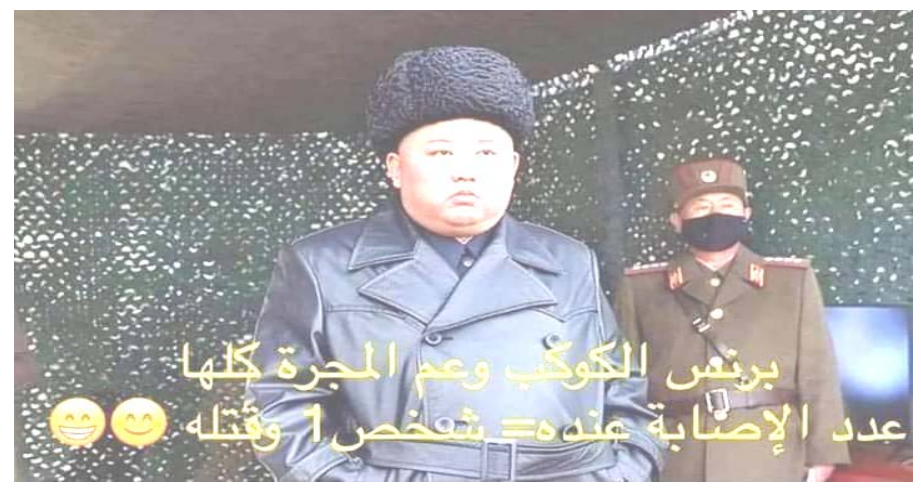

732 


\section{Humor and Social Media: A Linguistic Analysis of Some Egyptian Coronavirus Memes}

Dr. Menna Mohammed Salama El-Masry

مجلة وادي النيل للاراسات والبحوث الإنسانية والاجتماعية والتربوية (مجلة علمية محكمة)

Figure 7 is an image of Kim Jong-un, the leader of North Korea. Kim Jong-un is known for his abnormal decisions and his cruelty in dealing with many situations. The down caption consists of two lines, the first line is the setup of the meme which describes Kim Jong-un as an unusual and exceptional leader. This possible description is opposed with impossible script which appears in the punchline of the meme that says: "the number of the infected people in North Korea is only one and he has killed him". It is impossible for any reasonable president to kill the infected people in order to protect his country from coronavirus. The meme's producer employs exaggeration in order to make fun of the various rumors which tackle Kim Jung-un's abnormality. The meme depends on some colloquial Egyptian fixed expressions such as "brns El kwkab" (the prince of earth) and "am El magarah" (the king of the galaxy). Those two expressions are used in order to say that someone is exceptional in his deeds and this opposed with the punchline of the meme. The image here plays an important role because the main caption doesn't mention the name of Kim JungUn, it is the picture which facilitates understanding the text and realizing humor.

Script opposition: possible \& impossible.

Logical mechanism: exaggeration.

Target: Kim Jong-un, the president of North Korea.

Context: an image from one of the celebrities in North Korea which shows kim Jung-un, the leader of the country.

Verbal humor: satire 


\section{Figure 8:}

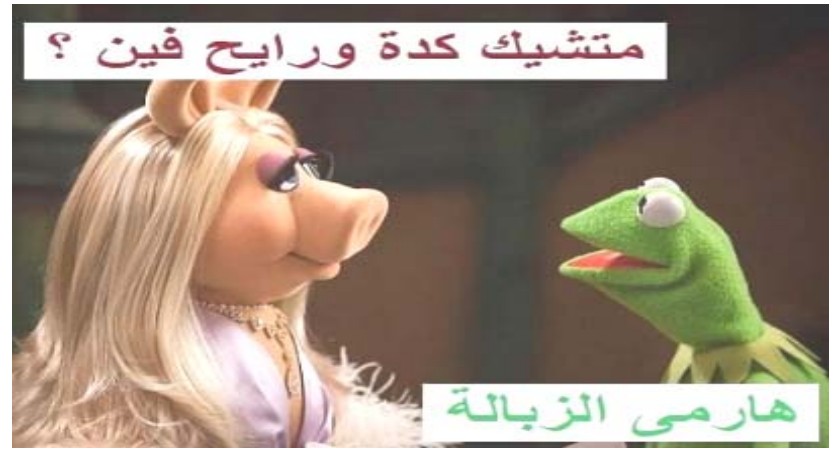

Figure 8 is an image of two famous puppet characters: Kermit the Frog and Miss Piggy pink. Kermit here adopts the role of the husband who sits with his family in the lockdown time. On the other hand, miss Piggy Pink is the Egyptian wife who asks her husband a usual question in the quarantine's time: "wow, you are a very well-groomed, where are you going?" Piggy Pink's question is the possible one being asked everyday by every Egyptian wife. The Possible script is opposite to the impossible one activated by Kermit's answer: "I am going to throw the garbage". Here, the act of dressing well opposes the act of throwing the garbage. The meme laughs at and satirizes the conditions of most Egyptian families in the quarantine time. Men are locked at their homes and they are prevented to meet their friends, so their only way to see the street is to throw garbage, the most hated action for men.

The meme's producer here exaggerates the situation in order to resolve the script opposition. The meme contains two colloquial expressions like "rayih fein" (where are you going) and "armi el zebala" (throw garbage).

Script opposition: possible \& impossible. - Wife \& husband.

Logical mechanism: exaggeration.

Target: the Egyptian family.

Context: conversation between Kermit and piggy pink.

Verbal humor: satire. 


\section{Humor and Social Media: A Linguistic Analysis of Some Egyptian Coronavirus Memes}

Dr. Menna Mohammed Salama El-Masry

مجلة وادي النيل للاراسات والبحوث الإنسانية والاجتماعية والتربوية (مجلة علمية محكمة)

Figure 9:

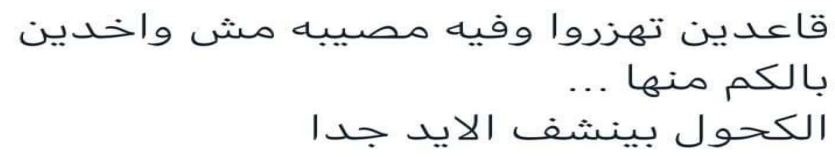

Translate Tweet

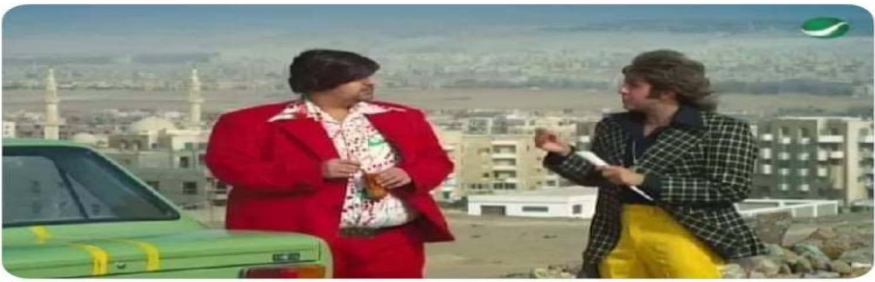

Figure 9 from the Egyptian movie Samir, Shahir and Bahir. The film tells a story of three brothers who went back to 1970. Bahir always worries about his appearance as he belongs to the aristocratic class. In this scene, Bahir talks with his brother Shahir (Shiko) about an important issue. They went back to the year 1970 and they are in a big dilemma. The meme's producer takes this critical situation and adds an interesting caption that says: "Guys, are you kidding? Actually, we are hit by a serious problem"! The respondents of the meme think that there is a critical issue that is coronavirus and its damageable effects. What causes laughter is the punchline of the meme which says: "alcohol makes our hands dry"! Here the meme's producer criticizes the exaggerated concern shown by ladies in the time of coronavirus as they don't care about the virus, but they are afraid that using alcohol makes their hands dry. Here, the actual problem of coronavirus contradicts with nonactual problem that women face and this creates a kind of script opposition which causes laugher. Exaggeration is used to solve script opposition. Moreover, the comparison or the analogy between the character of Bahir and Egyptian ladies clarifies the meme. The meme laughs at some Egyptian ladies whose main 
(ISSN : 2536 - 9555)

concern is that alcohol makes hand dry. The meme's caption is written in present tense and this brings the recipients into events. They can feel that they are a part of the problem. Moreover, using simple present tense enables the meme's producer to speak about a serious or important fact. Some Egyptian expressions like "bithazarow" (are you kidding) and " msh wakhden balkom" (you do not notice) asserts the meme's message.

Script opposition: actual \& non-actual

Logical mechanism: exaggeration \& analogy

Target: Egyptian women

Context: a scene from the Egyptian movie "Samir, Shahir and Bahir".

\section{Figure 10:}

$$
\text { الصا مش عاوزك تخافى خالص من الكورونا لانو بيستقر عل الاسطح }
$$

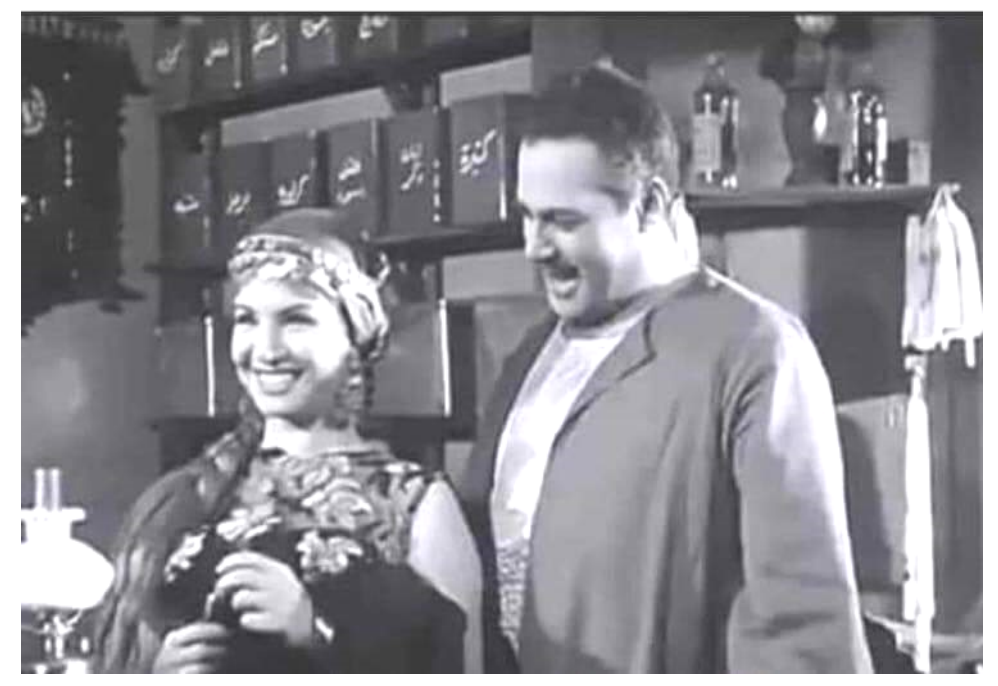




\section{Humor and Social Media: A Linguistic Analysis of Some Egyptian Coronavirus Memes}

Dr. Menna Mohammed Salama El-Masry

مجلة وادي النيل للاراسات والبحوث الإنسانية والاجتماعية والتربوية (مجلة علمية محكمة)

The image is originally taken from one of the scenes of the Egyptian film Byn Al Qasryn or (Palace Walk) in which the protagonist "Alsayed Ahmed Abdelgawad" (Yehia Shahin), who is known for his tyrannical character, speaks to "Alsultanah Zubydah" (Maha Sabry), the woman who falls in love with. Here, "Alsayed Ahmed Abdelgawad" tells her: "I don't want you to fear of coronavirus as it's settled on hard surfaces and you are malban agameyya".

Sex and non sex scripts are connected together in order to produce laughter. Another actual and non-actual script opposition has been clarified. The actual truth is that coronavirus settles on hard surfaces, but what is non-actual is that it will not settle on Zubydah's body because she's malban.

Script opposition is resolved through using analogy and exaggeration. Analogy emerges from the simile that is held between zubydah and the Egyptian sweet malban or agameyya which is made of gel of starch and sugar and it becomes light, fluffy, and chewy. The term malban also is used on colloquial Arabic as a courting word used by a lover who wants to praise his beloved beauty. Using present tense brings the respondents into the heart of the situation.

Script opposition: sex \& non sex - actual \& non-actual.

Logical mechanism: analogy \& exaggeration

Target: Egyptian people

Context: a scene from the Egyptian movie "Palace Walk".

Verbal Humor: satire 
Figure 11:

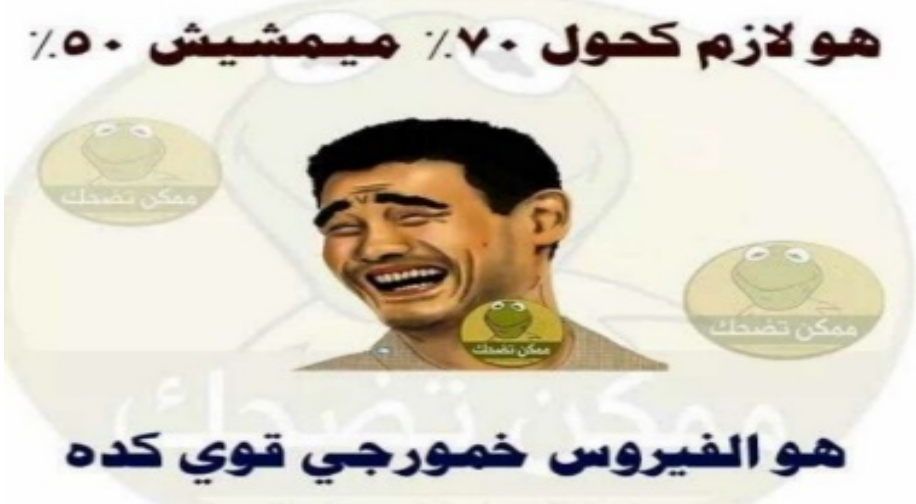

Figure 11 depicts a famous character in the Egyptian meme society which is "asa7be". Asa7be sarcasm society appears in 2012 as a comic page which criticizes and comments on the different social issues in the Egyptian society. Asa7be here comments on using alcohol to sterilize our hands during coronavirus pandemic saying: " Is it necessary to use 70\% alcohol? Doesn't 50\% alcohol kill viruses? It seems that coronavirus is alcohol addict". It is possible to ask so many questions about alcohol as it is said that $70 \%$ alcohol is the only effective type in fighting Corona. What is impossible is to describe coronavirus as an alcohol addict. The Logical mechanisms used in solving this opposition are analogy and exaggeration. It is a false analogy to describe the virus as alcohol addict. Both needs alcohol, but they are not similar. The meme's producer depends on using some colloquial expressions that suits asa7be character which exemplifies many Egyptian young men, for examples "mymshes" (it does not work) and "khamorgy" (alcohol addict).

Script opposition: possible \& impossible.

Logical mechanism: analogy \& exaggeration.

Target: Egyptian society.

Context: a meme from asa7be sarcasm society. 
Humor and Social Media: A Linguistic Analysis of Some Egyptian

Coronavirus Memes

Dr. Menna Mohammed Salama El-Masry

مجلة وادي النيل للاراسات والبحوث الإنسانية والاجتماعية والتربوية (مجلة علمية محكمة)

Type of verbal humor: satire

Figure 12:

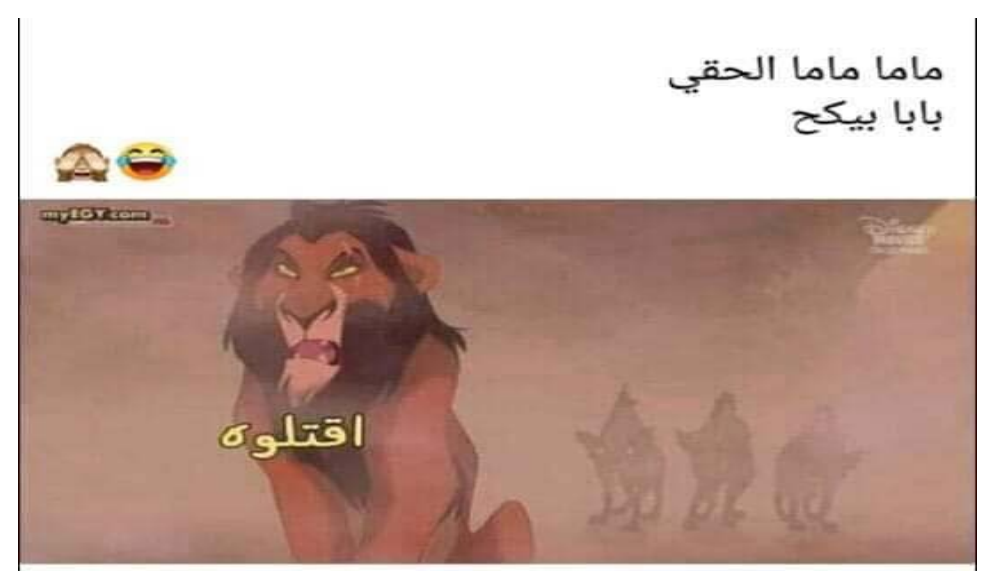

Image 12 is taken from the children animation The Lion King. Scar, Simba's wicked uncle, plots to kill Mufasa and usurp his throne. In this scene, scar orders his supporters (Shenzi, Banzai, and Ed) to kill Simba to get rid of him. The meme's producer connects Scar to the Egyptian mothers to mock the relationship between husbands and wives especially in Corona lockdown. It is possible for a child to tell his mother that his father has a cough. What is impossible is the mother's reaction "kill him". False analogy and exaggeration resolve this script opposition and create humour. When the Egyptian mother is described as wicked as Scar, this is humor. The punchline which consists of one word "kill him" causes contradiction which leads to laughter. The unexpected answer of the mother reveals the tension relation between husbands and wives especially at the time of the lockdown. The language of the meme is very simple. It consists of two colloquial expressions "alhaqy" (be careful) and "bykoh" (he has a cough). The jab line is a declarative sentence in which children inform their mother that their father has a cough and on the other hand the wife uses 
مجلة وادي النيل للاراسات والبحوث الإنسانية والاجتماعية والتربوية (مجلة علمية محكمة)

(ISSN : 2536 - 9555)

imperative statement which creates humor. Here, Image plays an important role in asserting and intensifying the text and it also alludes the tension relationship between Egyptian husbands and wives.

Script opposition: possible \& impossible

Logical mechanism: false analogy \& exaggeration

Target: the Egyptian families

Context: a scene from the animation cartoon The Lion King

Type of verbal humor: sarcasm

Figure 13:

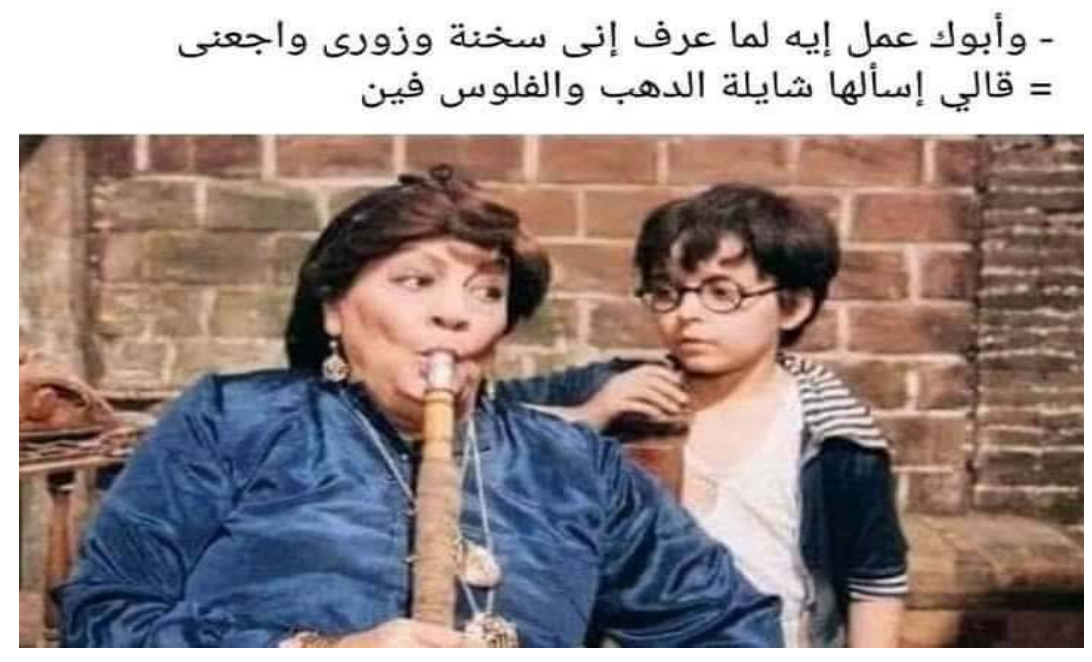

The image is cut originally from the Egyptian movie El -Afareet (The Demons). In the film, the daughter of a famous announcer "karima" (Madiha Kamel) is kidnapped by one of the followers of El - Kataa (Naima AL Soghayar), who is the leader of a gang of children. El - Kataa is a heartless woman who cares nothing but money. In this scene, the smart child Socrates tells El - Kataa an important issue, so she listens carefully to him. The meme's producer adds an interesting caption to this shot: "what does your 


\section{Humor and Social Media: A Linguistic Analysis of Some Egyptian Coronavirus Memes}

Dr. Menna Mohammed Salama El-Masry

$$
\text { مجلة وادي النيل للاراسات والبحوث الإنسانية والاجتماعية والتربوية (مجلة علمية محكمة) }
$$

father do when he knows that I have a fever and a sore throat?" Socrates says: "he asks me where you hide money and jewelry".

Sore throat and high fever are two basic symptoms of infection with Corona virus. So, in a normal conversation between a mother and her son she asks him what does your father do when he knows that I have a fever and a sore throat? The abnormal answer of the son causes script opposition and it expresses the relation between husbands and wives in the time of quarantine. Juxtaposition and exaggeration reveals the Script opposition. The language of the meme consists of some colloquial expressions like "abuk" (your father) and "amal ayh" (do) and "shayla" (hide). Alternating between past and present simple reinforces the situation and add power and interest to the conversation.

Script opposition: normal \& abnormal

Logical mechanism: juxtaposition \& exaggeration

Target: Egyptian families

Context: a scene from the Egyptian movie $A L$-Afareet

Type of verbal humor: sarcasm

Figure 14 :

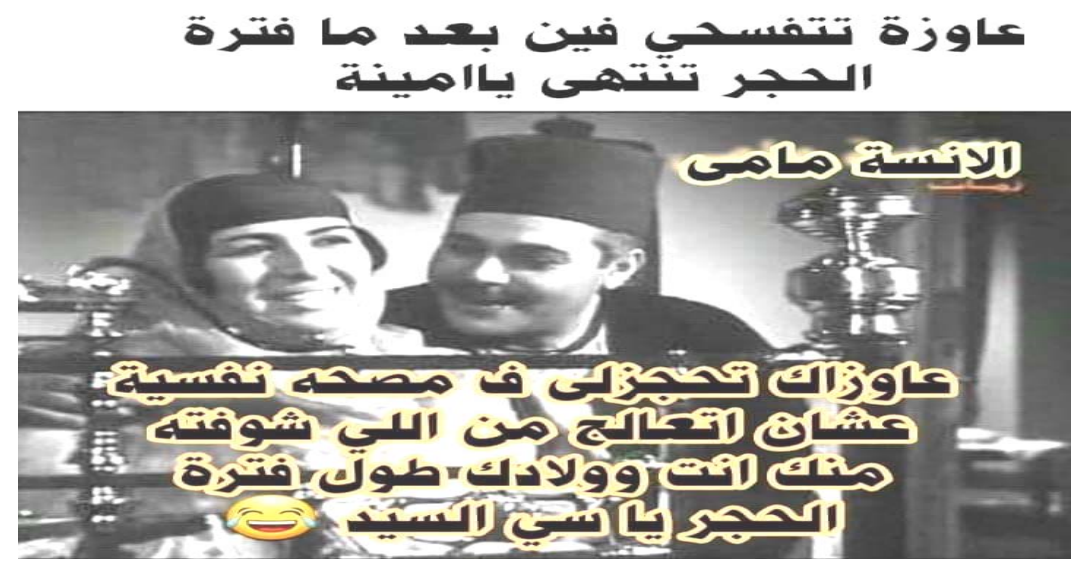


(ISSN : 2536 - 9555)

The meme's template describes a situation between the actress "Amal Zayed", who is known in the history of Egyptian cinema by Amina, and her patriotic husband Alsayed Ahmed abdelgawad "Yehia Shahin". The image is taken from one of the scenes of the Egyptian movie Byn El-Qasryn (Palace Walk) by Naguib Mahfouz. Understanding the plot of the film enables the respondents to understand humor. The film tells the story of Alsayed Ahmed Abdelgawad, who is a head of his household, demanding total obedience from his family members. On the other hand, Amina is an example of the suppressed wife who never says no. In this scene, Amina tells Si Alsayed the she dreams of going to the shrine of Al Hussain and he promises to take her one day. The meme producer exploits this relationship and adds a short conversation that causes script opposition. Alsayed Ahmed Abdelgawad asks his wife "where do you want to go after the lockdown, Amina? Amina says: "I want to go to a psychiatric hospital to recover from the mischievous and wild deeds you and your children perform during the lockdown, Si Alsayed." Here, it is possible for the husband to ask his wife this question but it's impossible for Si Alsayed to ask his humble Amina this question. Moreover, Amina's answer is also impossible. The possibility of the situation opposes the impossibility of Amina's and Si Alsayed's answers. The Logical mechanisms which resolve the opposition are role reversal and exaggeration. Alsayed Ahmed's question and Amina's answer reverse the situation or the roles of the two characters. In addition to that, Amina's words are exaggerated, and this causes humor. The meme takes the form of a conversation written in present tense to grab the viewer into the heart of the situation. Using some colloquial expressions clarifies the meme and makes it more understandable.

Script opposition: possible \& impossible

Logical mechanism: role reversal \& exaggeration

Target: the Egyptian family

Context: a scene from the Egyptian movie Palace Walk 
Humor and Social Media: A Linguistic Analysis of Some Egyptian

Coronavirus Memes

Dr. Menna Mohammed Salama El-Masry

مجلة وادي النيل للار اسات والبحوث الإنسانية والاجتماعية والتربوية (مجلة علمية محكمة)

Type of verbal humor: banter

Figure 15:
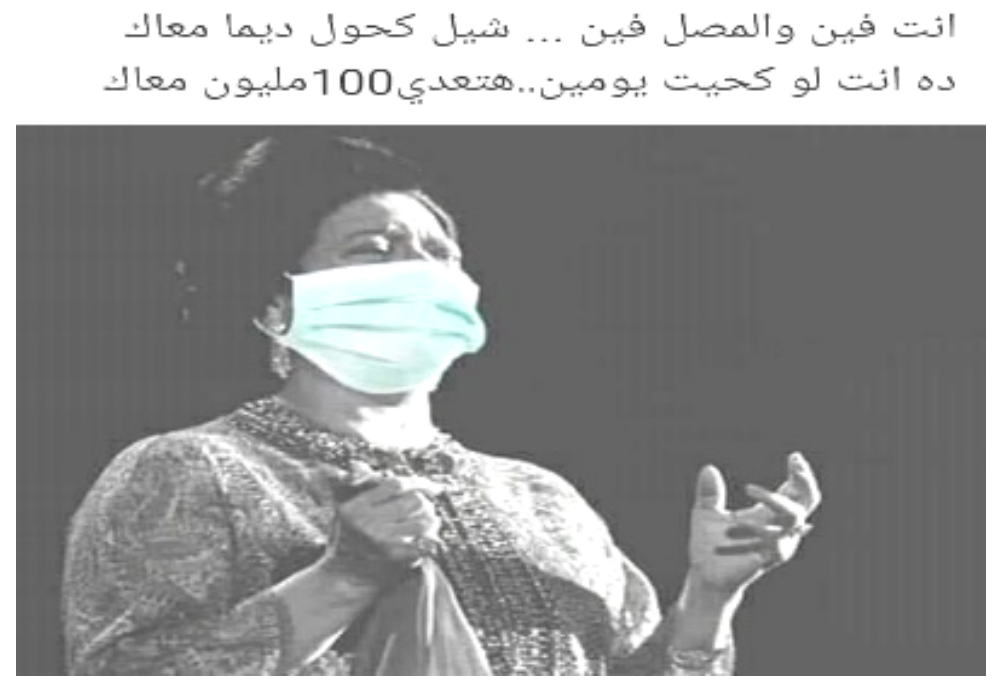

Figure 15 describes the great Egyptian singer "Umm Kalthoum" in one of her parties. The caption of the meme sheds light on her famous love song "Inta Feen". In the original song, Umm Kalthoum blames and censures her lover who does not know the meaning of true love which fills her heart. Using the same rhythm, the meme's creator wants to advice the Egyptian people in a comic way. He advises them to wear face masks and to stick to alcohol because there is no vaccine. The image of Umm Kalthoum, who is wearing the face mask, creates a kind of opposition. It is possible for everyone to wear face masks in the time of Corona virus, but it is impossible for the dead Umm Kalthoum to wear it in her party. Possible and impossible script opposition is resolved by a false analogy between the original song and the caption which is used in the meme. The text here is written in a poetic form. The meme's creator keeps the original rhythm to attract viewers' attention. 
(ISSN : 2536 - 9555)

Script opposition: possible \& impossible

Logical mechanism: false analogy

Target: the Egyptian society

Context: a shot from one of "Umm Kalthoum" parties.

Figure 16:
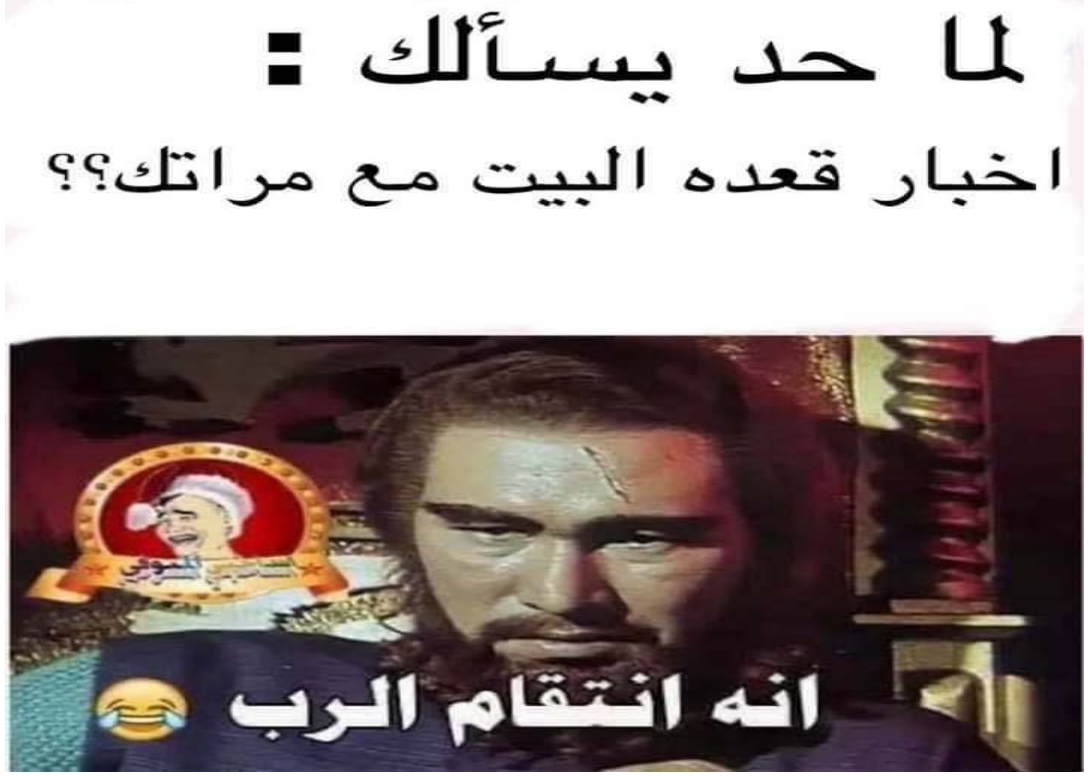

The template of this meme is adapted from the Egyptian movie "AL Nasser Salah Ad-din" or (Saladin the Victorious). The movie tells the story of AL Nasser Salah Ad-din who succeeds in returning Jerusalem back under the Muslims' rule. Hamdi Ghaith, the character in the meme's template, is king Richard the Lionheart of England. He is known for his power and his religious tendency. Moreover, he is the leader of the Third Crusade which aims to take Jerusalem back.

The meme's creator adds a humorous caption to the meme's template to create humor. Normal and abnormal script opposition is clear. When someone asks you "what about sitting with your 


\section{Humor and Social Media: A Linguistic Analysis of Some Egyptian Coronavirus Memes}

Dr. Menna Mohammed Salama El-Masry

$$
\text { مجلة وادي النيل للاراسات والبحوث الإنسانية والاجتماعية والتربوية (مجلة علمية محكمة) }
$$

wife at home?" and your answer is " it is the lord's revenge", it is abnormal answer. This unexpected answer with the image of the angry Hamdy Ghaith creates the normal and abnormal opposition. The Logical mechanisms which are used to understand script oppositions are juxtaposition and exaggeration. Here, the meme's producer connects the husband's sitting at home with the punishment. This exaggerated simile creates humor. The jab line of the meme is written in colloquial Egyptian Arabic and it contains some expressions like "akhbar" (news) and "qaedah" (sitting), while the punchline is written in formal Arabic "it is lord's revenge". The conversation form makes the viewer feel that he is in the position of the speaker. Moreover, the present simple tense reflects husbands and wives' problems.

Script opposition: normal \& abnormal

Logical mechanism: juxtaposition \& exaggeration

Target: Egyptian families

Humor type: sarcasm

Context: a scene from the Egyptian film Saladin the Victorious

Figure 17:

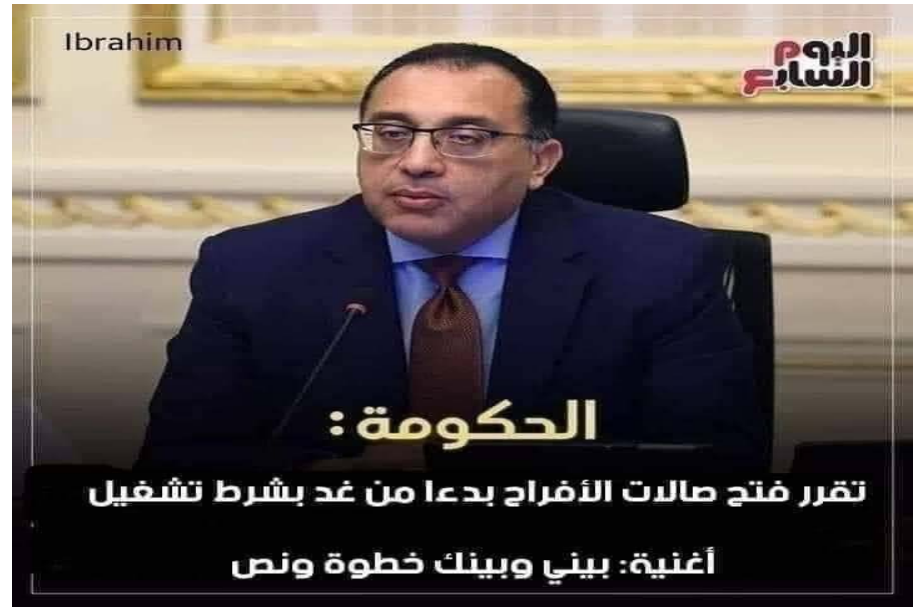


(ISSN : 2536 - 9555)

Figure 17 depicts the Egyptian prime Minister Mustafa Madboli in one of his meetings. The meme's producer adds an additional lower caption which takes the form of breaking news. The caption says: "the government has decided to reopen the wedding halls, but on the condition that they play the famous song bini we beink khatwa we nesf". It is possible for the government to declare at any time the opening of the wedding halls but is impossible that the main condition of this reopening is playing hakim's song bini we beink khatwa we nesf.

Faulty reasoning is used here to solve the possible and impossible script opposition. This song is used as a kind of a reminder which alerts the Egyptians that they must keep social distance. The language of the meme is clear, and it takes the form of breaking news and this adds power and attracts attention. Using declarative sentences enhance the form of the meme.

Script opposition: possible vs impossible

Logical mechanism: faulty reasoning

Target: Egyptian society

Context: a shot from one of the meetings of the prime minister Mustafa Madboli.

Type of verbal humor: satire

\section{Figure 18:}

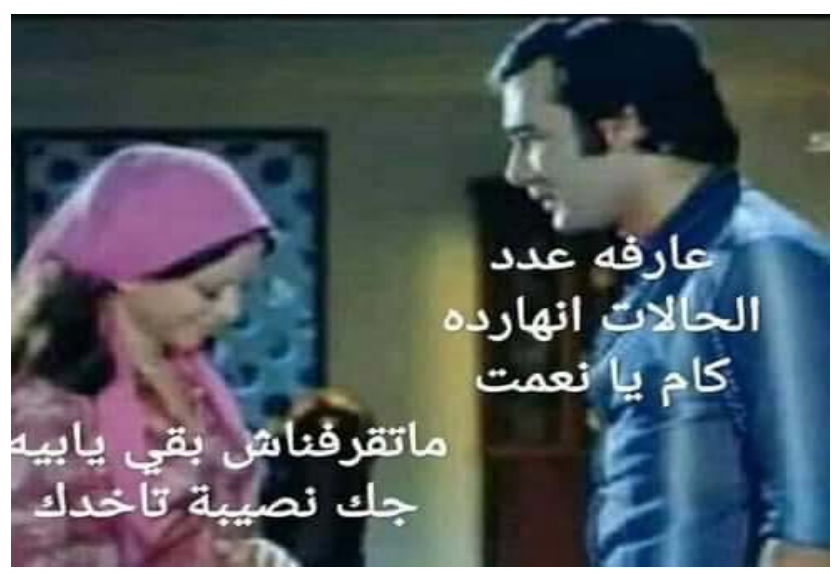




\section{Humor and Social Media: A Linguistic Analysis of Some Egyptian Coronavirus Memes}

Dr. Menna Mohammed Salama El-Masry

$$
\text { مجلة وادي النيل للاراسات والبحوث الإنسانية والاجتماعية والتربوية (مجلة علمية محكمة) }
$$

The template of figure 18 is cut from the Egyptian movie Afwah Wa Aranb which tells the story of a poor family with 10 kids who have so many problems. The aunt Nemat leaves home because her brother-in-law wants to get her married to a rich man. Nemat works as a servant and she falls in love with the rich and educated master, Mahmoud, who also loves her. The Story is compatible with the meme's caption and this causes normal and abnormal script opposition. This opposition is clarified through the mem's caption. To ask about the number of infected people is normal but Nemat's answer is abnormal. Nemat, the servant, rebukes her master for asking about today's number of infected people saying, " Leave me alone, bey. O Lord, a tribulation may strike you". So, role reversal plays a pivotal role in understanding script opposition.

The conversational form of the captain attracts the viewers. Besides the conversational form, the meme consists of some colloquial expressions which are used by all Egyptians, so that the viewer can find himself in place of the two participants: for examples "matqrefnash" (don't bother us) and " ya beyh jk neseybah takhdak" (O Lord, a tribulation may strike you).

Script opposition: normal vs abnormal

Logical mechanism: false analogy

Target: Egyptian society

Context: a scene from the Egyptian film Afwah Wa Aranb

Type of verbal humor: irony

Figure 19:

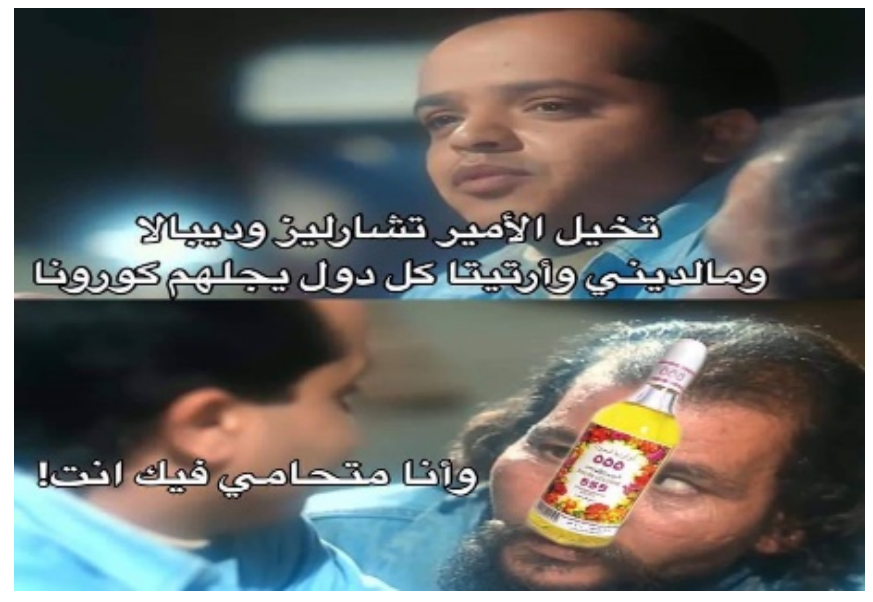


(ISSN : 2536 - 9555)

The image is cut from one of the scenes of the Egyptian film Hammam Fe Amsterdam (Hammam in Amsterdam). It is an imaginative conversation between Mohammed Henedy and five fifth cologne. Henedy here is a symbol of all Egyptians who believe in the rumors which say that five fifth cologne can protect you from coronavirus. Henedy addresses five fifth cologne saying, "prince Charles, Maldini and Artita are infected with Corona and I believe that you can protect me from the virus!". Actually, Prince Charles, Maldini and Artita are infected by Corona, but it is a nonactual rumor that five fifth cologne can protect from coronavirus. Juxtaposition between Prince Charles, Maldini and Artita and all Egyptians resolves the actual and non-actual script opposition. The language of the conversation is clear and simple, and it suits Henedy who is a symbol of all Egyptians.

Script opposition: actual vs non-actual

Logical mechanism: juxtaposition

Target: Egyptian Society

Context: a scene from the Egyptian movie Hammam in Amsterdam

Type of verbal Humor: sarcasm

Figure 20:

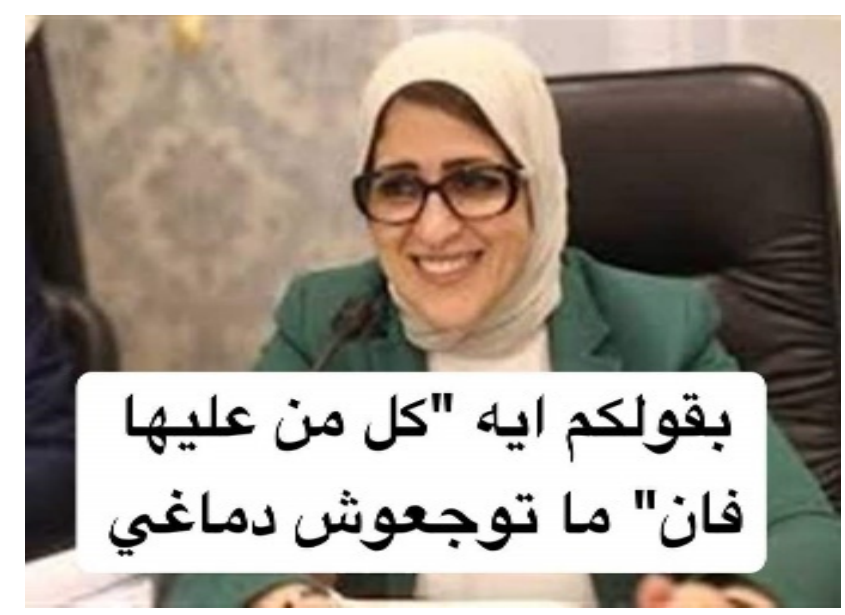




\section{Humor and Social Media: A Linguistic Analysis of Some Egyptian Coronavirus Memes}

Dr. Menna Mohammed Salama El-Masry

مجلة وادي النيل للاراسات والبحوث الإنسانية والاجتماعية والتربوية (مجلة علمية محكمة)

Figure 20 depicts the health minister Hala Zayed, who is assigned before Corona virus pandemic. The low caption which says "look, everyone upon the earth will perish, don't disturb me" contradicts with the image of the health minister who is supposed to be responsible for this pandemic. Possible and impossible script opposition affirms itself as it is impossible for the health minister to utter such words. Role reversal explains the Script opposition. The language of the meme contains some colloquial expression that do not suit the educated minister of health such as "baqwlkm ayh" (look) and "matwjaush demaghy" (don't disturb me).

Script opposition: possible vs impossible

Logical mechanism: role reversal

Target: Egyptian Society

Context: a shot depicts health Prime Minister Hala Zayed

Type of verbal humor: satire

\section{Conclusion}

Memes are complicated multimodal texts which affect our understanding and create a satirical and mocking view at the society and its social, economic, and political problems. In this research, the researcher has analyzed 20 Egyptian internet memes about Corona virus pandemic to identify the different techniques and strategies used to create humor in internet memes. The analysis shows that, in several memes, humor is based mainly on the attached texts, while the visual element plays a secondary supporting role by providing a detailed background of the meme. Through the image, the meme's viewer can connect the main situation of the film or the movie with the main topic of the meme. This juxtaposition creates humor and triggers laughter. In addition to that, the meme's template can work as a jab line or a bunch line 
مجلة وادي النيل للاراسات والبحوث الإنسانية والاجتماعية والتربوية (مجلة علمية محكمة)

(ISSN : 2536 - 9555)

and this affirms the collaboration between the verbal and the visual elements to produce humor.

A close look to the examined memes reveals that the most frequent type of script opposition used by memes' producers is the possible/impossible one which occurs 10 times, while normal and abnormal script opposition occurs 5 times. The third frequent type is actual/nonactual opposition that recurs 4 times. It is also clear that analogy and juxtaposition are the common logical mechanisms used to produce humor and to resolve script opposition. In most memes analogy and juxtaposition are accompanied with exaggeration which triggers laughter. Exaggerating the given situation enables the viewers to laugh. Similarly, analogy and juxtaposition affirm the strong bond between visual and verbal element. Role reversal, parallelism and faulty reasoning are also used here to resolve script opposition.

The analysis also proves that Attardo's notions of jab line, punchline and the $5 \mathrm{KRs}$ are useful in analyzing humor in memes, which is an example of a still multimodal text. Moreover, a wide range of research on visual humor needs to be elaborated.

\section{References:}

Abdalian, A. (2005). Why is that Funny? An Extension to the Semantic Script Theory of Humour. Swarthmore College: Swarthmore College Press.

Adel, M. (2019). Memes: A Game Changer in Egyptian Politics. Al-ahram online, www.English. Al-ahram.org.eg.

Anugrahputra,R. \&Triyono, S. (2016). The Diversity of Internet Memes Interpretations: A Discourse Analysis of Incongruity of Popular Memes Made by Indonesian Netizen. Journal of Linguistics and Education, (6) 2, 49-61.

Attardo, S. (1994). Linguistic Theories of Humor. Berlin: Mouton De Gruyter.

Attardo, S. (2000). Irony as Relevant Inappropriateness. Journal of Pragmatics, 32, 793- 826. 
Humor and Social Media: A Linguistic Analysis of Some Egyptian

Coronavirus Memes

Dr. Menna Mohammed Salama El-Masry

مجلة وادي النيل للاراسات والبحوث الإنسانية والاجتماعية والتربوية (مجلة علمية محكمة)

Attardo, S. (2001). Humorous Texts: A Semantic and Pragmatic Analysis. Berlin: Mouton De Gruyter.

Attardo, S., Hempelmann, Ch. \& Maio, D. S. (2002). Script Oppositions and Logical Mechanisms: Modelling Incongruities and Their Resolutions. Journal of Humour, (15), 1, 3-64.

Attardo, S. (2003). Introduction: The Pragmatics of humor. Journal of Pragmatics, 35, 1287-1294.

Attardo, S. (2007). Irony as Relevant Inappropriateness. In H. Colstone, R. Gibbes (Eds.), Irony in Language and Thought: A Cognitive Science Reader (pp.127-135). Lawrence Elbaum Press.

Attardo, S. (2014a). Humour in Language. In Salvatore Attardo (Ed.), Encyclopedia of Humour Studies (pp.2-20). Oxford University Press.

Attardo, S. (2014b). Incongruity and Resolution. In Salvatore Attardo (ed.), Encyclopedia of Humour studies (pp.384386). Oxford University Press.

Attardo, S. (2014c). Jokes. In Salvatore Attardo (ed.), Encyclopedia of Humour Studies (pp.418- 420). Oxford University Press.

Attardo, Salvatore (2018). Universals in Puns and Humorous Wordplay. In Esme winter \& Verene Thaler (Eds.), Cultures and Traditions of Wordplay and Wordplay Research (pp.87-111). Oxford University Press.

Chovanec, J. \& Ermida, I. (2012). Language and Humour in the Media. Cambridge: Scholars Publishing.

Davidson, Patrick (2012). The Language of Internet Memes: Social Media Reader. New York: New York Press.

Dynel, M. (2006). Political Memes as Tools of Dissent and Alternatives Digital Activism in the Russian-Language Twitter. University of Westminster Press. 
(ISSN : 2536 - 9555)

Dynel, M. (2009). Beyond a Joke : Types of Conversational Humour. Language and Linguistics Journal. (3) 5, 12841299.

Dynel, M. (2014). Linguistic Approaches to Non-Humorous Irony. Journal of Humor, 27 (6), 537-550.

Elkhachab, Ch. (2018). Living in Darkness: Internet Humour and the Politics of Egypt's Electricity Infrastructure (MA. Thesis): Wolfson College.

Freud, Sigmund (1960). Jokes and Their Relation to the Unconscious. London: Routledge.

Gibbs, R.W. (1994). The Poetics of Mind, Figurative Thought, language and Understanding. New York: Cambridge University Press.

Goldstein, J. \& Meghee, N. (1972). The Psychology of Humor. New York: Academic Press

Grice, P. (1975). Logic and Conversation. Syntax and Semantic Journal, 3, 41-58.

Hempelmann, F., Ch. \& Attardo, S. (2011). Resolution and Their Incongruities: Further Thoughts on Logical Mechanisms. Journal of Humor, (4) 2, 125-149.

Hempelmann, F., Ch. (2014). Puns. In Salvatore Attardo (Ed.), Encyclopedia of Humour Studies (pp.613-615). Oxford University Press.

Hockett, Ch. (1977). Jokes. In C.F. Hockett (ed.), The View from Language. Athens: University of Georgia press.

Joshua, Samuel (2020). A Pragmatic Analysis of the Discourse of Humor and Irony in Selected Memes on Social Media. International Journal of Language and literary studies. (2), 2, pp.76-95.

Kostadinovska, B. \& Shalevska, E. (2018). Internet Memes and Their Socio-Linguistic Features. European Journal of Literature, Language and Linguistic Studies, (2) 4, 158169. 
Humor and Social Media: A Linguistic Analysis of Some Egyptian

Coronavirus Memes

Dr. Menna Mohammed Salama El-Masry

مجلة وادي النيل للاراسات والبحوث الإنسانية والاجتماعية والتربوية (مجلة علمية محكمة)

Lehikoinen, O. (2012). Positive (Im) politeness: Banter As a Form of Social Cohesion in Internet Chat. University of Turku: Turky.

Monoro, M. (1953). Argument of Laughter. Melbourne: Melbourne University Press.

Morreall, J. (1987). The Philosophy of Laughter and Humor. Albany: State University of New York Press.

Mulder, M.P. \& Nijholt, A. (2002). Humour: State of Art. CTIT Technical Report Series, 2, 1-34.

Norrick, N. (1984). Stock Conversational Witticism. Journal of Pragmatics, 8, 195-209.

Norrick, N. (1993). Conversational Joking: Humour in Everyday Talk. Bloomington: Indian university Press.

Norrick, N. (2003). Issues in Conversational Joking. Journal of Pragmatics, 35, 1333-1359.

Oltean, A. (2014). An Application of The General Theory of Verbal Humour to Kurt vonnegute's "Cat's Craddle". Cultural Journal, IX (1), 130-150.

Ostanina, J. \& Majdzinska, A. (2019). A Cognitive Linguistic Approach to Internet memes on Selected Polish Internet Sites. Cognitive Studies Journal, 19, pp.1-11.

Ortega, Alvarado (2013). An Approach to Verbal Humour in Interaction. Social and Behavioral Sciences, 95, 594-603.

Partington, S. A. (2009). A Linguistic Account of Wordplay: The Lexical Grammar of Punning. Journal of Pragmatics, 41, 1794-1809.

Raskin, V. (1985). Semantic Mechanisms of Humor. Dordrecht: Reidel.

Raskin, V. \& Attardo, S. (1991). Script Theory Revisited: Joke Similarity and Joke Representation Model. International Journal of Humour Research, 3 (4), 293-348. 
(ISSN : 2536 - 9555)

Ritchie, G. (2004). The Linguistic Analysis of Jokes. London: Routledge.

Rochmawati, D. (2017). Pragmatic and Rhetorical Strategies in English-Written Jokes. Indonesian Journal of Applied Linguistics, 7 (1), 149-159.

Shifman, Limor (2014). Memes in Digital Culture (MA. Thesis): MIT Press.

Shubeck, K. \& Huette, S. (2015). Predicting Memes Success With Linguistic Features in a Multilayer Back Propagation Network. International Journal of Humour, (5), 2180-2186.

Sulis, E., Irazu, D., Rosso, P., Patti, V. \& Ruffo, G. (2016). Figurative Messages and Affect in Twitter: Differences Between Irony, Sarcasm and Not. Knowledge-Based System Journal, 108, 132-143.

Taylor, M., J. (2014). Linguistic Theories of Humour. In Salvatore Attardo (Ed.), Encyclopedia of Humour Studies (pp.456458). Oxford University Press.

Tomoioaga, Anca (2015). Language and Discourse: A Linguistic Analysis of Jokes. Language and Discourse Journal, (21), 1, 159-166.

Vousden, J. (1996). Serial Control of Phonology in Speech production. University of Warwick: Coventry.

William, J.M. (1940). An Analysis of Humour and Laughter. American Journal of Psychology, 35, 70-85.

Westwood, Robert. (2008). Humour. In Stewart, Clegg \& James Bailey (Eds.), International Encyclopedia of Organization Studies (pp.621-625). London: Routledge.

Zabalbeascoa, P. (2008). The Nature of Audiovisual Text and its Parameters. In Diaz-Cintas (Ed.), Didactics of Audiovisual Translation (pp.21-73). Benjamin Translation Library.

www.Oxford Online Dictionary. Com. 